\title{
The conserved actinobacterial transcriptional regulator FtsR controls expression of $f t s Z$ and further target genes and influences growth and cell division in Corynebacterium glutamicum
}

\author{
Kim Julia Kraxner, Tino Polen, Meike Baumgart ${ }^{*}$ [D and Michael Bott ${ }^{*}$
}

\begin{abstract}
Background: Key mechanisms of cell division and its regulation are well understood in model bacteria such as Escherichia coli and Bacillus subtilis. In contrast, current knowledge on the regulation of cell division in Actinobacteria is rather limited. FtsZ is one of the key players in this process, but nothing is known about its transcriptional regulation in Corynebacterium glutamicum, a model organism of the Corynebacteriales.

Results: In this study, we used DNA affinity chromatography to search for transcriptional regulators of fts $Z$ in $C$. glutamicum and identified the Cg1631 protein as candidate, which was named FtsR. Both deletion and overexpression of ftsR caused growth defects and an altered cell morphology. Plasmid-based expression of native ftsR or of homologs of the pathogenic relatives Corynebacterium diphtheriae and Mycobacterium tuberculosis in the $\Delta f t s R$ mutant could at least partially reverse the mutant phenotype. Absence of ftsR caused decreased expression of ftsZ, in line with an activator function of FtsR. In vivo crosslinking followed by affinity purification of FtsR and next generation sequencing of the enriched DNA fragments confirmed the fts $Z$ promoter as in vivo binding site of FtsR and revealed additional potential target genes and a DNA-binding motif. Analysis of strains expressing fts $Z$ under control of the gluconateinducible gntK promoter revealed that the phenotype of the $\Delta f t s R$ mutant is not solely caused by reduced fts $Z$ expression, but involves further targets.

Conclusions: In this study, we identified and characterized FtsR as the first transcriptional regulator of FtsZ described for C. glutamicum. Both the absence and the overproduction of FtsR had severe effects on growth and cell morphology, underlining the importance of this regulatory protein. FtsR and its DNA-binding site in the promoter region of fts $Z$ are highly conserved in Actinobacteria, which suggests that this regulatory mechanism is also relevant for the control of cell division in related Actinobacteria.
\end{abstract}

Keywords: DNA affinity chromatography, Transcriptional regulation, ChAP-Seq, Corynebacterium diphtheriae, Mycobacterium tuberculosis, Rv1828

\footnotetext{
* Correspondence: m.baumgart@fz-juelich.de; m.bott@fz-juelich.de IBG-1: Biotechnology, Institute for Bio- und Geosciences, Forschungszentrum Jülich, 52425 Jülich, Germany
}

(c) The Author(s). 2019 Open Access This article is distributed under the terms of the Creative Commons Attribution 4.0 International License (http://creativecommons.org/licenses/by/4.0/), which permits unrestricted use, distribution, and reproduction in any medium, provided you give appropriate credit to the original author(s) and the source, provide a link to the Creative Commons license, and indicate if changes were made. The Creative Commons Public Domain Dedication waiver (http://creativecommons.org/publicdomain/zero/1.0/) applies to the data made available in this article, unless otherwise stated. 


\section{Background}

Bacterial reproduction is usually characterized by cellular growth followed by binary fission of a mother cell into two daughter cells. During this process, the bacteria need to coordinate several distinct processes such as DNA replication, biogenesis of the new cell wall, and the division process itself. Although the overall process is similar, several different concepts have evolved in distinct bacterial groups. Escherichia coli and Bacillus subtilis represent two of the best studied species in this respect $[1,2]$. Corynebacterium glutamicum is a nonpathogenic, facultative anaerobic, Gram-positive soil bacterium frequently used as model organism for the order Corynebacteriales, which includes important pathogens such as Corynebacterium diphtheriae and Mycobacterium tuberculosis causing the fatal infectious diseases diphtheria and tuberculosis [3-6]. C. glutamicum strains are used in industrial biotechnology for the production of L-amino acids and other metabolites, as well as for proteins [7-11].

One of the key players of cell division is the highly conserved and essential FtsZ protein, which is present in most bacteria. It is the first protein that moves to the future division site, polymerizes into a ring structure, and serves as scaffold for the assembly of further cell division proteins [12]. The resulting protein complex is called the divisome and drives the constriction during cell division [13]. Interestingly, Actinobacteria such as C. glutamicum lack homologs of several important cell division-related genes described for E. coli or B. subtilis. One of these is MreB, an actin homolog essential for lateral cell wall elongation in E. coli, Caulobacter crescentus, and B. subtilis [14-16]. In contrast to these species, $C$. glutamicum inserts new cell wall material at the poles, representing an apical elongation mechanism [17]. Another protein absent in $C$. glutamicum is FtsN, an essential membrane protein of $E$. coli with a potential role in coordination of cell division $[1,18]$. However, most strikingly is the complete absence of homologs of many known spatial and temporal, positive and negative regulators of cell division such as fts $A$, ezrA, $n o c / \operatorname{sim} A, z a p A$, and $\min C D E[18,19]$. This implies that cell division in the Corynebacteriales and probably other Actinobacteria is regulated through proteins and mechanisms that differ significantly from previously described ones.

To date, we have only a limited understanding of the regulation of cytokinesis in Corynebacteriales [18]. Accurate expression of fts $Z$ is critical for normal growth of C. glutamicum and $M$. tuberculosis and small variations lead to severe morphological changes and affect cell viability [19-21]. Thus, the FtsZ level has to be tightly regulated, which is supported by different studies of the fts $Z$ promoter region showing a very complex transcription of fts $Z$ in various actinobacteria [19, 22-24]. Current knowledge on transcriptional regulation of fts $Z$ expression in C. glutamicum is sparse. A complex of the DNA-binding proteins WhiA (Cg1792) and WhcD (Cg0850) was reported to bind to the fts $Z$ promoter region [25], however, the effect of this interaction on fts $Z$ expression remains to be elucidated. We previously showed that the FtsZ protein can be phosphorylated in vitro by the serine/threonine protein kinases $\mathrm{PknA}$, $\mathrm{PknB}$, and $\mathrm{PknL}$ and is an in vivo substrate of the phosphoSer/Thr protein phosphatase Ppp [26], suggesting that the properties and activities of FtsZ can also be influenced by posttranslational regulation [18].

In this study, we identified and characterized the transcriptional regulator Cg1631 of C. glutamicum as an activator of fts $Z$ expression. Therefore, Cg1631 was renamed FtsR, standing for fts $Z$ regulator. We show that FtsR is critical for normal growth and cell morphology of $C$. glutamicum, suggesting an important role of this protein in the regulation of cell division.

\section{Results}

\section{Search for transcriptional regulators of $\mathrm{fts} Z$}

To investigate transcriptional control of fts $Z$, we searched for potential regulators by DNA affinity chromatography using a $417 \mathrm{bp}$ DNA fragment covering the 3 '-end of the $f t s Q$ coding region (36 bp), the intergenic region between $f t s Q$ and fts $Z$, and the first 96 bp of the fts $Z$ coding region. The immobilized DNA fragment was incubated with crude protein extract of C. glutamicum wild type cells. The proteins eluting after several washing steps were separated by SDS-PAGE. Subsequent MALDI-ToF-MS analysis resulted in the identification of eight proteins (Fig. 1, Additional file 1: Table S1). Six of them represent proteins that are often

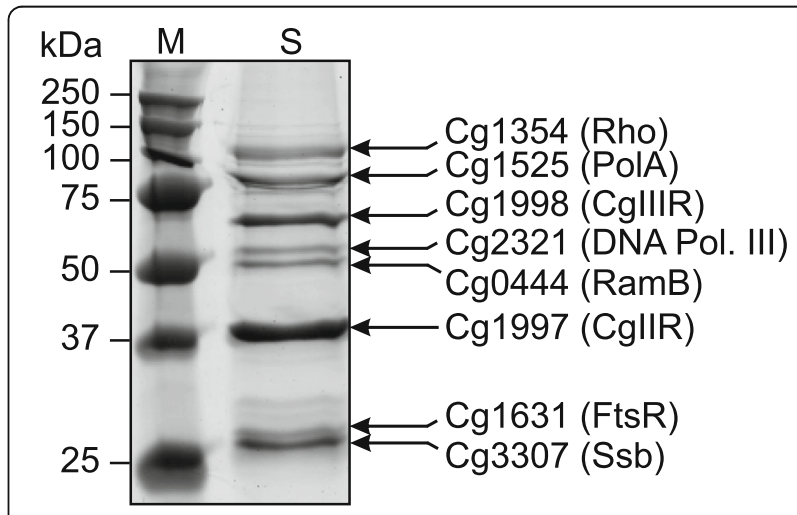

Fig. 1 DNA affinity chromatography with the fts $Z$ promoter region. Crude cell extract of C. glutamicum ATCC13032 cultivated in glucose minimal medium to the mid-exponential growth phase was incubated with an immobilized 417-bp DNA fragment covering the $\mathrm{fts} Z$ promoter region and strongly binding proteins were eluted with a high-salt buffer. Proteins enriched with the fts $Z$ promoter were separated by SDS-PAGE, stained with colloidal Coomassie, and identified by peptide-mass fingerprinting using MALDI-ToF MS analysis (Additional file 1: Table S1). The band with an apparent mass of about 27 kDa was identified as FtsR. M, marker; S, sample 
found in DNA affinity purifications with C. glutamicum cell extracts independent of the promoter region used. These are the single-stranded DNA-binding protein Ssb (Cg3307), the restriction endonucleases CglIR (Cg1997) and CglIIR (Cg1998), the $\varepsilon$-subunit of DNA polymerase III (Cg2321), DNA polymerase I (Cg1525), and the transcription termination factor Rho (Cg1354). Most interesting were the remaining two proteins, both of which are annotated as transcriptional regulators, Cg0444 (RamB) and Cg1631. The identity of these two proteins was further verified by MS/MS analysis of selected peptides (Additional file 1: Table S1). The regulator of acetate metabolism RamB (Cg0444) has already been studied quite extensively and represses genes involved in acetate metabolism and alleviates glucose and sucrose uptake [27, 28]. A function in ftsZ regulation has not been described for RamB and a wellconserved RamB-binding site (AA/GAACTTTGCAAA [28]) is absent from the fts $Z$ promoter region. In contrast to RamB, the function of the second transcriptional regulator enriched with the fts $Z$ promoter fragment, Cg1631, was completely unknown and Cg1631 was therefore the focus of this study. Due to its role in fts $Z$ regulation, the protein was named FtsR.

\section{FtsR, a MerR-type transcriptional regulator conserved in Actinobacteria}

The gene ftsR (cg1631) of C. glutamicum ATCC13032 encodes a protein of 252 amino acids (calculated mass $27.23 \mathrm{kDa}$ ), which was annotated as a transcriptional regulator of the MerR family due to the sequence similarity of the N-terminal region of FtsR to other members of the MerR family. The ftsR gene and its immediate genomic vicinity including the upstream gene odhI (cg1630) and the two downstream genes (cg1632 and cg1633) were found to be highly conserved within the Actinobacteria (Fig. 2). The odhI gene encodes the 2oxoglutarate dehydrogenase inhibitor protein OdhI, which acts as a phosphorylation-dependent switch controlling the activity of the 2-oxoglutarate dehydrogenase complex [33-35]. The homologous protein of

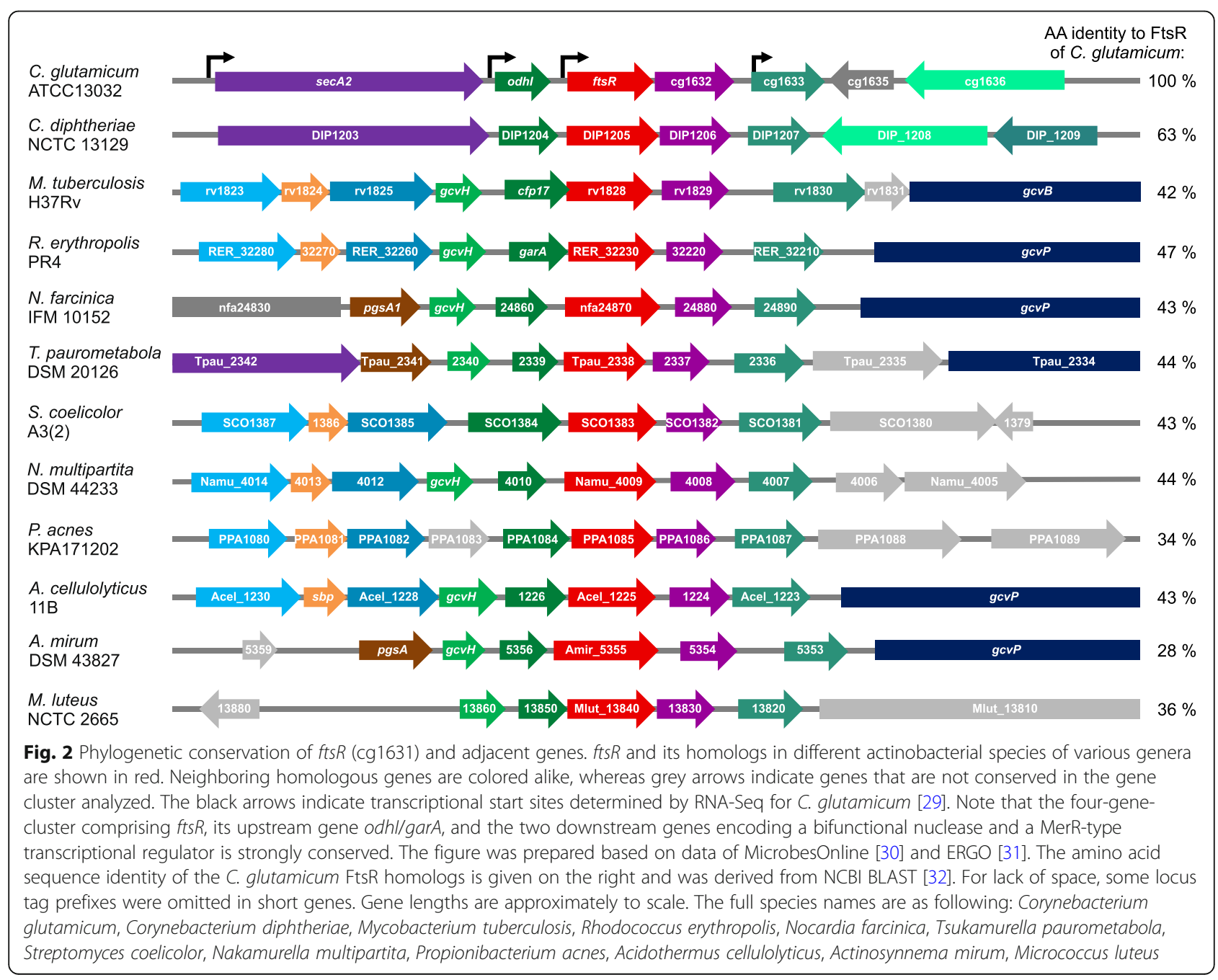


mycobacteria is GarA [36]. The gene cg1632 encodes a putative bifunctional nuclease having both DNase and RNase activity (PFAM PF02577), and cg1633 encodes another yet uncharacterized transcriptional regulator of the MerR family. Previous RNAseq analysis indicated that ftsR is co-transcribed with these neighboring genes in various combinations: cg1629-cg1633 was annotated as primary operon and cg1630-cg1633 and cg1631cg1633 as sub-operons [29] (Fig. 2). The genomic region upstream of odhI (cg1630) and downstream of cg1633 varies in different Actinobacteria.

An amino acid sequence alignment of FtsR homologs of different actinobacterial species revealed that especially the $\mathrm{N}$-terminal part is highly conserved (Additional file 1: Figure S1). Two features of the alignment are conspicuous, which are the variable length of the N-termini upstream of the highly conserved region starting with the sequence MSIG and the variable length of the region linking the N-terminal DNA-binding domain and the Cterminal regulatory domain.

\section{Deletion and overexpression of fts $R$ affects growth behavior and cell shape}

To gain insights into the function of FtsR in C. glutamicum, an in-frame ftsR deletion mutant as well as an ftsRoverexpressing strain were constructed (Additional file 1: Tables S2 and S3) and analyzed with respect to growth behavior and cell morphology. Remarkably, the ftsR deletion strain grew significantly slower and to a lower final cell density (backscatter) compared to the wild type in CGXII minimal medium with glucose as carbon source (Fig. 3a). The consequences of ftsR overexpression in the wild-type strain ATCC13032 were tested using plasmid pAN6-ftsR, in which ftsR expression is controlled by the tac promoter. The promoter is known to be leaky in C. glutamicum and allows basal expression of the target gene also in the absence of the inducer IPTG [37]. Without IPTG and with IPTG concentrations up to $10 \mu \mathrm{M}$, growth of ATCC13032 pAN6-ftsR was comparable to the reference strain ATCC13032 pAN6. However, when $100 \mu \mathrm{M}$ IPTG was added, growth of ATCC13032 pAN6-ftsR was strongly inhibited (Fig. 3b). Thus, both the absence and the overexpression of fts $R$ had negative consequences. We searched our in-house microarray database with more than 1700 experiments for conditions with altered ftsR mRNA levels, but found no evidence for transcriptional regulation of $f t s R$. Together, these results suggest that ftsR expression in the cell may be constitutive.

Phase-contrast and fluorescence microscopy with staining of DNA and membranes revealed strong morphological differences to wild-type cells both for the $\Delta f t s R$ mutant and for the ftsR overexpressing strain (Fig. 3c, Additional file 1: Figure S2). These differences were apparent both in the exponential and stationary growth phases (Additional file 1: Figure S3). While the phenotype of the $\Delta f t s R$ mutant did not change much along the cultivation, the phenotype of the overexpression strain became more severe over time (Additional file 1: Figure S3). This could be due to an accumulation of FtsR in the cells resulting from the overexpression. The $\Delta f t s R$ cells were elongated and some of them were branched (Fig. 3c, black arrow). Several cells had multiple septa at different positions in the cell. Overexpression of $f t s R$ led to enlarged cells with DNA accumulated at the poles (Fig. 3c, black circle). These cells also contained additional septa, which were mostly located in the middle of the cells. However, only a fraction of the cells was enlarged, whereas the others remained small and inconspicuous. Please note that the small cells appear DNA-free in some pictures because the brightness was adjusted to the cells with the high DNA concentration. All small cells of the FtsR overexpression strain seem to contain similar DNA amounts like the wild type. The reason for this population heterogeneity is unknown at present. It could result from different FtsR levels in the cells due to heterogeneous induction of pAN6-based ftsR expression, as previously reported for eyfp expression by the pAN6 parent plasmid pEKEx2 [38]. The observed morphological changes caused by ftsR deletion and overexpression, in particular the presence of multiple septa within a single cell that did not lead to a separation of the cells, hint toward a function of FtsR in cell division and to a potential role in the regulation of $f t s Z$ expression. To further evaluate the changes in cell size or rather cell volume, we analyzed the strains using a Coulter counter in the volumetric measurement mode. Additional file 1:Figure S4 shows the size distribution at three different time points during cultivation $(3 \mathrm{~h}, 6 \mathrm{~h}, 24 \mathrm{~h})$. For the $\Delta f t s R$ strain in comparison to the wild type, the whole population was shifted to larger cell sizes at all time points and formed a single broad peak. The population of the $f t s R$ overexpressing strain formed two peaks of different sizes at $24 \mathrm{~h}$, differing weakly or strongly in size from wild type carrying pAN6. As mentioned above, this could be due to heterogeneous expression from plasmid pAN6-ftsR. Overall, these measurements confirmed that the ftsR deletion strain comprises a homogeneous population of cells with increased size in different growth phases. In contrast, the strain overexpressing fts $R$ showed a homogeneous population of enlarged cells in the exponential growth phase, and interestingly two populations with cells of different sizes in the stationary phase, which matches the. These results coincide with the cells size distribution observed by microscopy. 

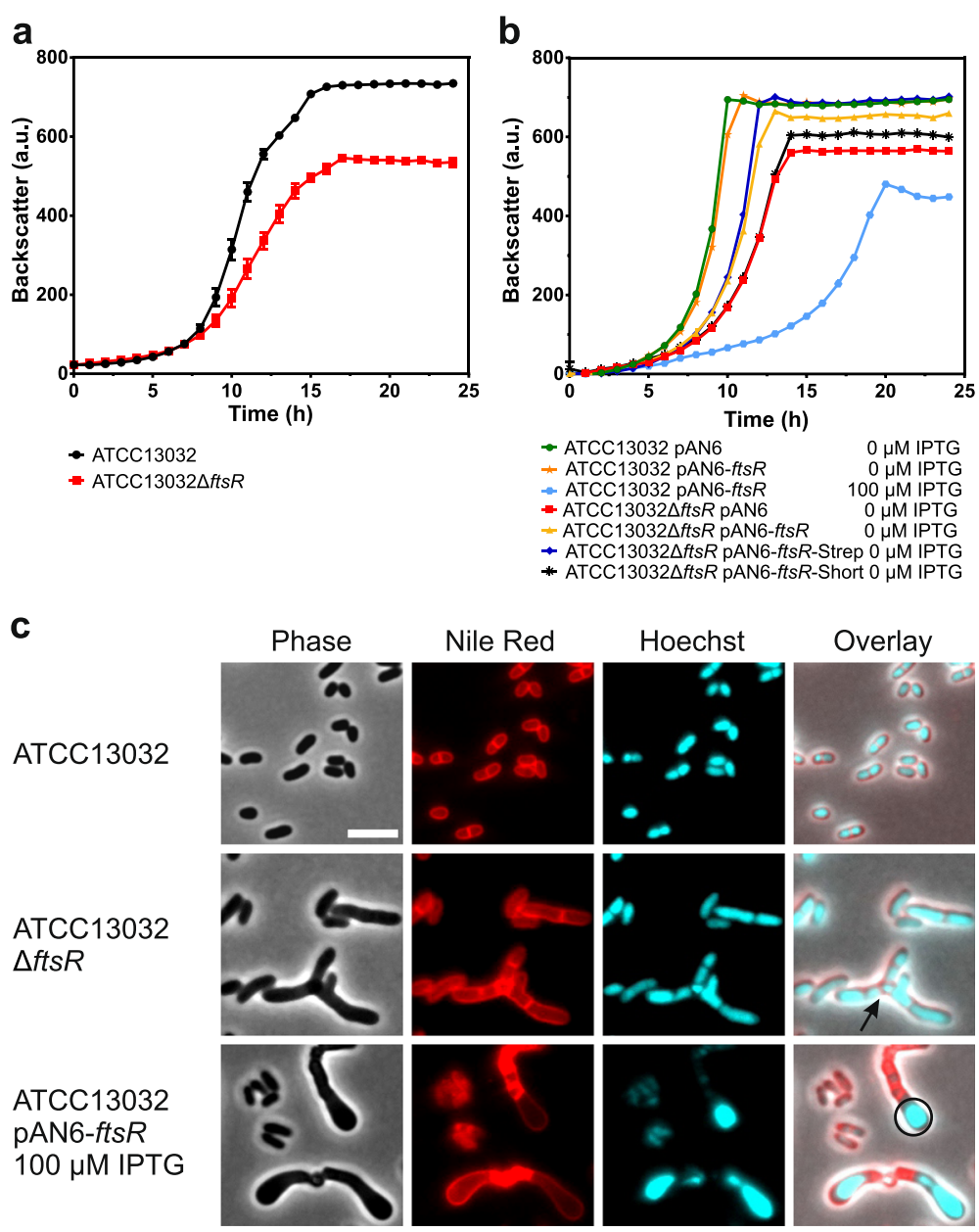

Fig. 3 Growth behavior and cell morphology of C. glutamicum $\Delta f t s R$ and C. glutamicum overexpressing ftsR. a Growth of the ftsR deletion mutant in comparison to the wild type. Mean values and standard deviation of three biological replicates are shown. $\mathbf{b}$ Growth of an fts $R$ overexpressing strain and complementation of the $\Delta f t s R$ mutant with several FtsR variants including an $\mathrm{N}$-terminally shortened protein and a protein with a Cterminal StrepTag-II. Average values from two biological replicates are shown. For the growth experiments shown in $\mathbf{a}$ and $\mathbf{b}$, the strains were pre-cultivated first in BHI medium and then in CGXII medium with $2 \%(\mathrm{w} / \mathrm{v})$ glucose, followed by the main cultivation in the same medium. For b, all media were supplemented with kanamycin $(25 \mu \mathrm{g} / \mathrm{mL})$ and IPTG as indicated. c Microscopic pictures of cells in the stationary phase. To visualize membranes and DNA, cells were stained with Nile Red and Hoechst 33342, respectively. The arrow points towards a branched cell and the circle indicates a high DNA concentration at the cell pole. The scale bar represents $5 \mu \mathrm{m}$

In order to corroborate the results described above, the ftsR gene was also deleted and overexpressed in another C. glutamicum strain termed MB001, which differs from ATCC13032 by the deletion of the three prophage regions CGP1 (13.5 kb), CGP2 (3.9 kb), and CGP3 $(187.3 \mathrm{~kb})$ [39]. We previously reported that the MB001 strain behaved like its parent wild type in the majority of conditions tested, but showed improved growth and fitness under SOS response-inducing conditions that trigger CGP3 induction in the wild type. Thus, MB001 is a useful strain background for the analysis of deletions causing stressed cells, as secondary effects due to prophage induction are excluded. Both growth behavior (Additional file 1: Figure S5) and cell morphology of MB001 $\Delta f t s R$ (Additional file 1: Figure S6) were comparable to that of ATCC13032 $\mathrm{ftsR}$, and also overexpression of ftsR in MB001 caused similar effects as in ATCC13032 (Additional file 1:Figure S5). Thus, the absence of the prophages CGP1, CGP2, and CGP3 had no obvious influence on the effects of ftsR deletion and overexpression on growth and cell morphology.

\section{Complementation of the $\Delta f t s R$ phenotype with native} FtsR and homologs of $C$. diphtheriae and $M$. tuberculosis To confirm that the growth defect and the altered cell morphology of the $\Delta f t s R$ mutants are caused by the ftsR deletion rather than by secondary mutations that might have occurred during construction of the mutants or polar effects on downstream genes, complementation experiments were performed with plasmid pAN6-ftsR 
and two variants thereof. Plasmid pAN6-ftsR-Strep encodes an FtsR variant with a carboxyterminal linker sequence (AS) followed by a Streptag-II (WSHPQFEK). Plasmid pAN6-ftsR-short encodes an FtsR variant shortened by 28 amino acids at the $\mathrm{N}$-terminus, which is now MSIGV. An alternative start codon was found here, based on the amino acid sequence alignment reported above (Additional file 1: Figure S1). As shown in Fig. 3b, the growth defect of ATCC13032 $A$ ftsR pAN6 could partially be reversed by pAN6-ftsR and pAN6-ftsR-Strep, but not by pAN6-ftsR-short. This suggests that the longer FtsR variant composed of 256 amino acid residues represents the active protein and that its function is not disturbed by a C-terminal Streptag-II. Furthermore, the morphological changes of ATCC13032 $\mathrm{fts} R$ could be fully reversed by pAN6-ftsR. When the complementation was performed with strain $\mathrm{MB} 001 \Delta \mathrm{fts} R$, a full reversal of the growth defect and of the morphological changes was observed for MB001 $\triangle$ ftsR pAN6-ftsR without IPTG induction (Additional file 1:Figures S5, S6). These results confirm that ftsR deletion causes the growth defect and the morphological changes of the corresponding mutants.

Due to the high conservation of the ftsR locus in different actinobacterial species, we assumed a similar function of the homologous genes and proteins. To test this hypothesis, we expressed ftsR homologs of two pathogenic relatives, CDC7B_1201 of Corynebacterium diphtheriae C7 and Rv1828 of Mycobacterium tuberculosis H37Rv, in the C. glutamicum MB001 $\Delta$ ttsR strain using pAN6-based expression plasmids, and monitored growth and cell morphology. While this manuscript was in preparation, initial biochemical and structural studies of Rv1828 were published [40], which will be discussed alongside our results. With pAN6-CDC7B_1201 almost full reversal of the growth defect and of the morphological changes was achieved by basal expression without IPTG induction (Additional file 1: Figure S6). As previously observed for overexpression of C. glutamicum ftsR, stronger induction of CDC7B_1201 gene expression had a negative effect on growth (data not shown). With pAN6-rv1828, the best complementation was achieved in the presence of $100 \mu \mathrm{M}$ IPTG (Additional file 1: Figure S6). Whereas a full reversal to wild-type morphology was observed, growth was improved with pAN6rv1828 but did not reach the wild-type characteristics. These results strongly suggest that the FtsR homologs of Actinobacteria have similar or identical functions and target genes.

\section{Transcriptome comparison of the ATCC13032 $\Delta$ ftsR mutant with its parent wild type}

In order to elucidate the effects of ftsR deletion on fts $Z$ expression, but also on global gene expression as a first step towards definition of the FtsR regulon, transcriptome comparisons of the ATCC13032 $\Delta$ ftsR mutant versus the parent wild type were performed using DNA microarrays and RNA isolated from cells cultivated in glucose minimal medium and harvested in the exponential growth phase. 34 genes showed $\mathrm{a} \geq 2$-fold increased mRNA level and 18 genes $a \geq 2$-fold decreased mRNA level in the $\triangle f t s R$ mutant (Additional file 1: Table S4). Both the upregulated and the downregulated genes covered a broad and heterogeneous range of cellular functions. Within the group of genes showing a decreased mRNA level, the fts $Z$ gene with an mRNA ratio of 0.35 was the most prominent one. A reduced expression of fts $Z$ in the $\Delta f t s R$ mutant, combined with the fact that FtsR was enriched with the fts $Z$ promoter region, hints at a possible transcriptional activator function for FtsR. The group of upregulated genes included $o p p C$ and $o p p D$ encoding components of a putative ABC-type peptide transport system, four prp genes involved in propionate or propionyl-CoA catabolism, seven genes located in the CGP3 prophage region, which in total extends from cg1890 to cg2071, and a cluster of eight neighboring genes (cg0830 - cg0838) including those for an ABC-type trehalose uptake system. Interestingly, genome-resequencing revealed that the genome region comprising cg0830-cg0838 was amplified, which presumably caused the increased mRNA levels of these genes in the transcriptome analysis (Supplementary results, Additional file 1: Table S5, Additional file 1: Figure S7).

\section{Effect of ftsR deletion on ftsZ promoter activity and FtsZ distribution}

As an in vivo approach to demonstrate transcriptional activation of fts $Z$ expression by FtsR, a transcriptional fusion of the fts $Z$ promoter to a reporter gene encoding the mVenus protein was constructed resulting in plasmid pJC1- $\mathrm{P}_{\text {fts }}$-venus. The reporter plasmid and, as negative control, the parent plasmid $\mathrm{pJC1}$-venus-term were used to transform strains MB001 and MB001 $\Delta f t s R$ and fts $Z$ promoter activity was measured as cell-specific fluorescence (defined as ratio of fluorescence and backscatter). As shown in Fig. 4, the lack of ftsR caused a significantly lower specific fluorescence, supporting activation of $f t s Z$ expression by FtsR. Comparable results were obtained with strains ATCC13032 and ATCC13032 $\Delta$ ftsR carrying pJC1- $\mathrm{P}_{f t s} \mathrm{~A}^{-v e n u s}$ (Additional file 1: Figure $\mathrm{S} 8$ ).

To test whether the lack of FtsR influences the distribution of FtsZ within the cell, we generated derivatives of ATCC13032 and ATCC13032 $\mathrm{fts} R$ with a chromosomal insertion of a second copy of fts $Z$ fused in frame to the coding sequence of the fluorescent protein mVenus under control of the native fts $Z$ promoter. Both 
strains were cultivated in CGXII minimal medium with glucose as carbon source and analyzed by fluorescence microscopy (Additional file 1:Figure S9). In the strain lacking FtsR, the frequency as well as the intensity of the FtsZ rings was reduced. This may be caused by a reduced availability of FtsZ within the cells, which might contribute to the morphological phenotype of the ftsR deletion mutant.

\section{Genome-wide profiling of in vivo FtsR binding sites}

With the aim to identify the in vivo binding site of FtsR in the ftsZ promoter region and to identify further target
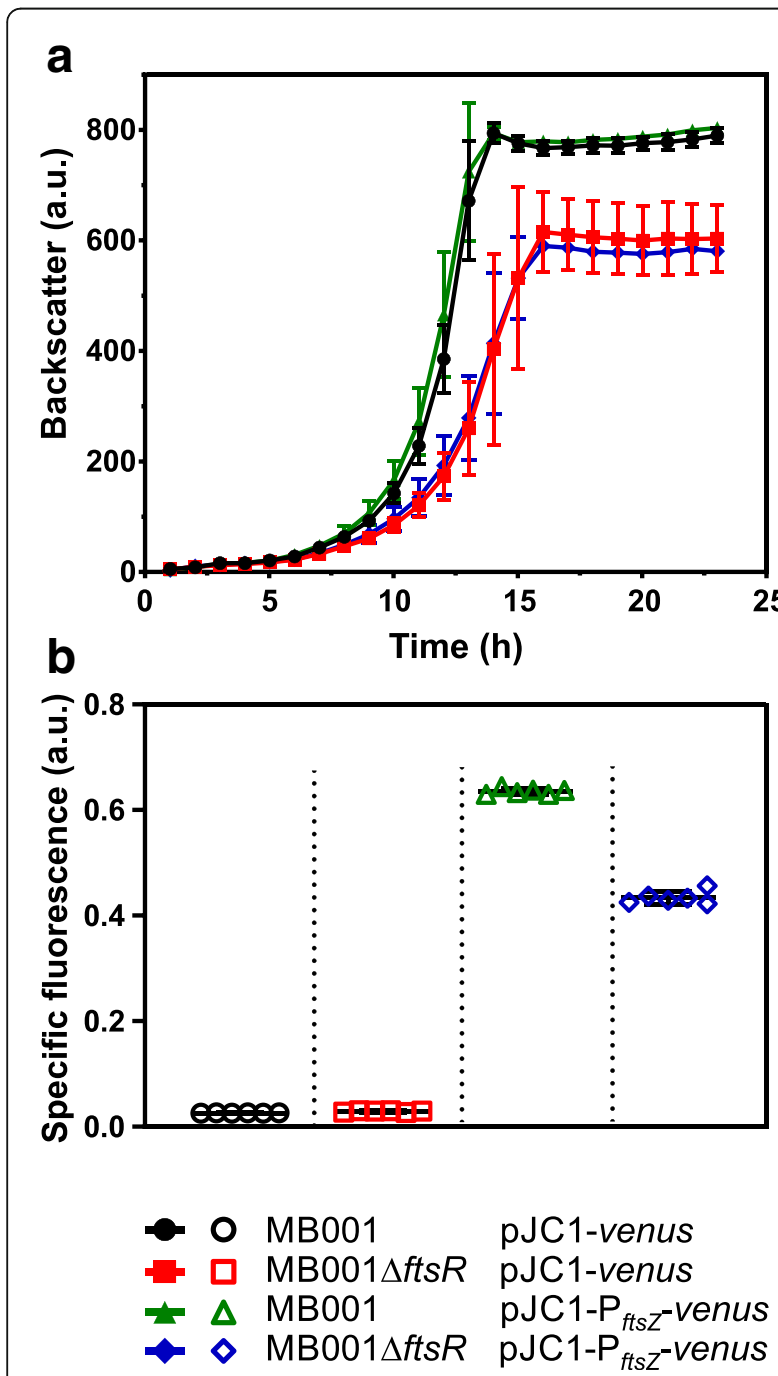

Fig. 4 Influence of the ftsR deletion in C. glutamicum MB001 on the expression of the venus reporter gene under control of the $\mathrm{fts} Z$ promoter. The indicated strains were cultivated in CGXII medium with $2 \%$ (w/v) glucose and $25 \mu \mathrm{g} / \mathrm{mL}$ kanamycin in a BioLector with automated measurement of Venus fluorescence and of cell density as backscatter (a). Specific fluorescence represents the ratio of fluorescence and backscatter at $20 \mathrm{~h}$ cultivation (b). Average values and standard deviations of three biological replicates are shown (a) b shows the result of six biological replicates genes of FtsR, a ChAP-Seq experiment was performed. In vivo formaldehyde-crosslinked FtsR-Strep-DNA complexes were purified by StrepTactin-affinity chromatography and the isolated DNA fragments were sequenced. Nine peaks with a sequencing coverage above 2000 were detected, which is at least 50 -fold higher than the background noise signal observed for the entire genome with a 40-fold coverage (Table 1, Fig. 5a, Additional file 1: Figure S10). The nine peaks were analyzed with respect to their chromosomal location and the mRNA level of the neighboring genes (Table 1). Based on the mRNA ratios observed in the transcriptome comparison of $C$. glutamicum ATCC13032 $\Delta$ ftsR vs. ATCC13032, three potentially FtsR-activated genes (ftsZ, cg0852, cg2477) and five potentially FtsR-repressed genes (cop1-cg3181cg3180, phoC, cg0838) were identified using mRNA ratio $(\Delta f t s R /$ wild type) cutoffs of 1.5 and 0.75 . A repetition of the ChAP-Seq experiment confirmed the results of the first one except that the overall coverage was lower and the order of the peaks varied slightly (Table 1 ).

The genes cg0852 and cg2477 encode conserved proteins of unknown function. The putative operon cop1-cg3181-cg3180 encodes three secreted proteins [42]. The Cop1 protein (also termed Csp1) was shown to function as mycolyltransferase involved in the conversion of trehalose monocorynomycolate to trehalose dicorynomycolate $[42,43]$. The protein encoded by phoC was proposed to function as cell-wall-associated phosphatase $[44,45]$ and is induced under phosphate-limiting conditions [46]. The cg0838 gene is part of the DNA region found to be amplified in the ATCC13032 $\triangle \mathrm{fts} R \mathrm{mu}-$ tant but had a higher mRNA ratio than the neighboring genes that were also amplified (Additional file 1: Table S5), pointing to a possible repression by FtsR. The large Cg0838 protein $(179 \mathrm{kDa})$ is proposed to function as an ATP-dependent helicase and contains a unique C-terminal domain including a metal-binding cysteine cluster.

The search for a common DNA sequence motif in the nine sequences with a coverage above 2000 using the MEME software [41] revealed the motif shown in Fig. 5b. The motif was identified in eight of the nine sequences except for the sequence with a coverage of 2871 . When looking at the corresponding motif in the fts $Z$ promoter region, it forms an imperfect 25-bp inverted repeat: AACCCTAAAGTAAAGGTTGAGGGTA. The center of this motif was located at position -73 with respect to the transcriptional start site of $f t s Z$ as determined by RNASeq [29]. This position is compatible with an activating function of FtsR for ftsZ expression (Fig. 5c). It should be mentioned that in C. glutamicum strain ATCC13689, five transcriptional start sites were identified for $f t s Z$ by primer extension and RACE studies [19], none of which corresponds to the one identified by RNA-Seq for strain ATCC13032 [29]. 


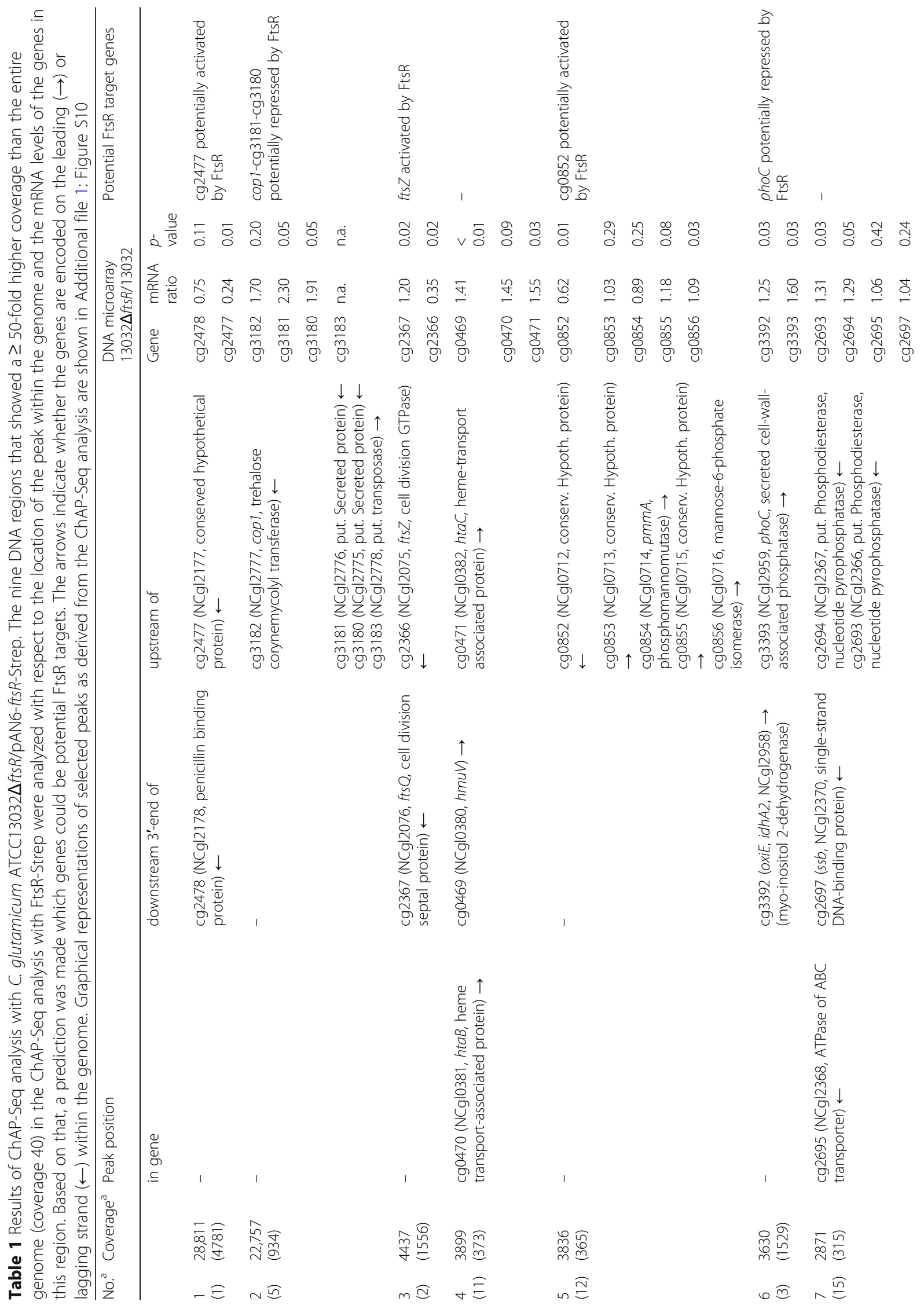




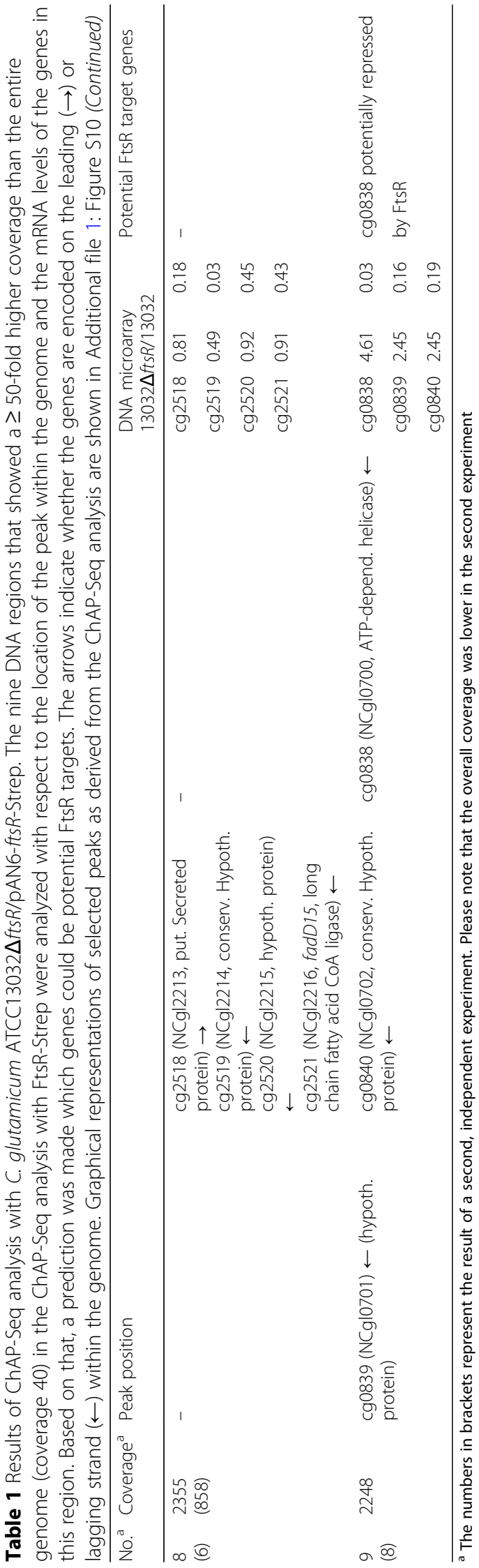




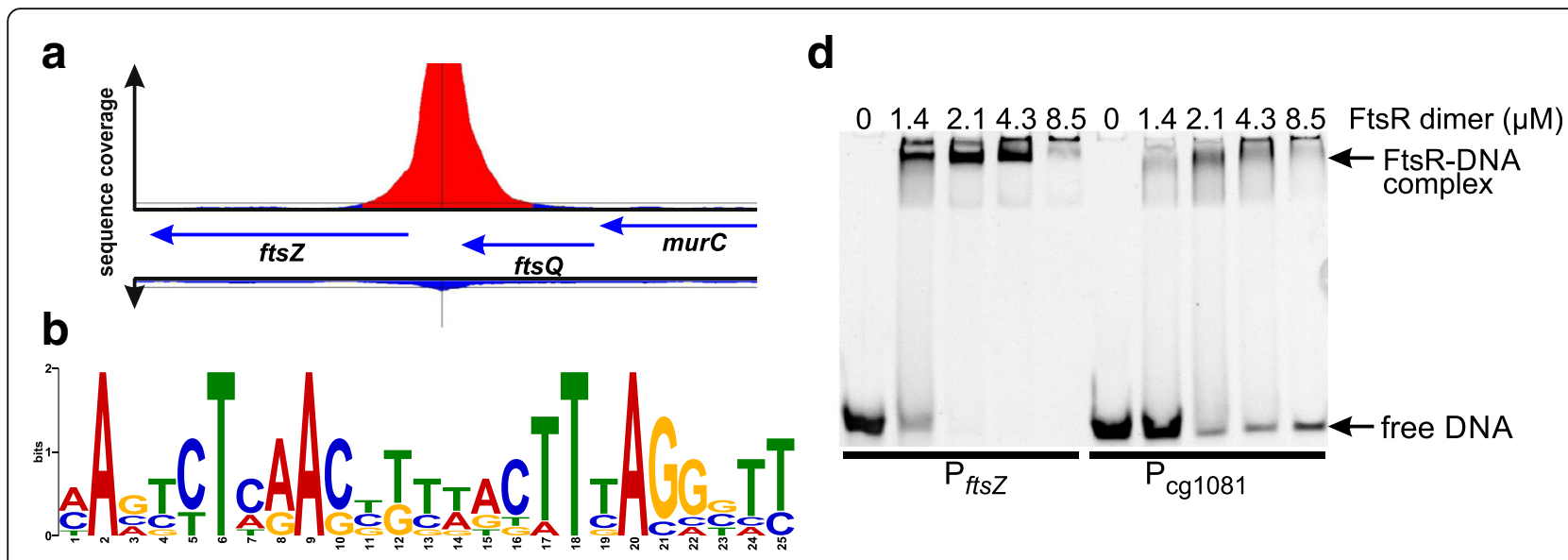

C

CACCCCCGGT GGGAACAgTA GAAGTTTCTG GCGCGGATGA AgGAAACtCA GAAGTGCTTC CTGCGgTTAT TGCTGTAATC AACGCAATTA

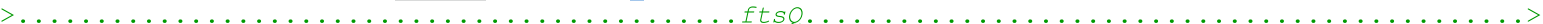

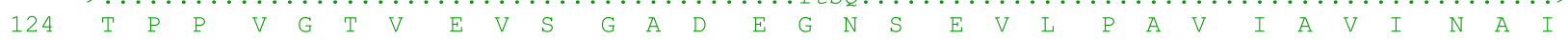
AAgCGCAAGA TGCGCAGATG ACAgAAAGTA TCCAGGTAGT GGAAGCTCCG GATCAATTTG ATATCTTGCT GAAAATGAAT GATGGCCGGG

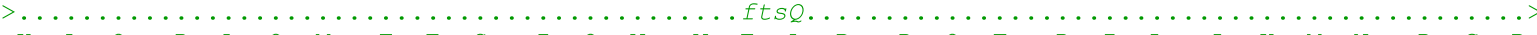

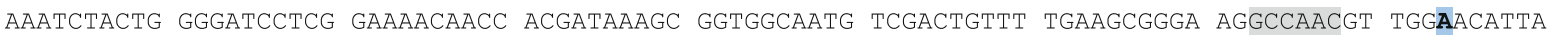

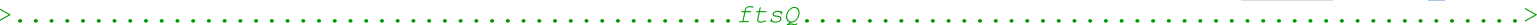

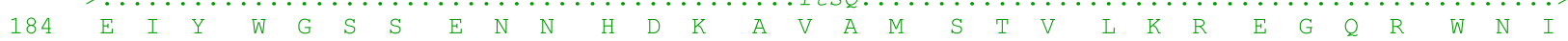
GCTCACCCTC AATGGTGACA GTCCGCTAAA GTGGCTGGGT AGTTCCGGTT CACCCGTTTC CACAACGCGT TTGCCCACCT CAACAACCCT $>\ldots \ldots \ldots \ldots+$.

$\begin{array}{lllllllllllllll}214 & S & S & P & S & M & V & T & V & R & -\end{array}$

\begin{abstract}
AAAGTAAAGg TTGAGGGTAG CGACACGCCG CTGTAAATGT CCGACACATT GACGTGTTTT TCGCACAAGA TATATGTCAG CCGGATTAAC $-10$ TS

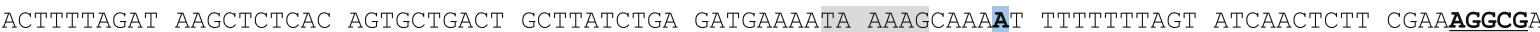
GACATCGACA ATGACCTCAC CGAACAACTA CCTCGCCAAG ATTAAGGTCG TCGGCGTGGg CGGCGGCGGA GTCAACGCCG TCAACCGCAT

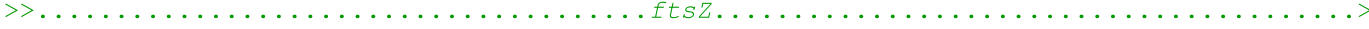

Fig. 5 Binding of FtsR to the ftsZ promoter. a Enrichment of the ftsZ promoter region in the ChAP-Seq experiment with FtsR-Strep. The negative control is presented below the genes. $\mathbf{b}$ FtsR consensus DNA-binding motif identified by the MEME software [41] using the nine DNA regions with the highest coverage in the ChAP-Seq experiment with FtsR-Strep. c DNA sequence of the ftsZ promoter region including parts of the coding regions of $\mathrm{fts} Q$ and $\mathrm{fts} Z$ and the corresponding amino acid sequences. The ribosome binding site of $\mathrm{fts} Z \mathrm{is}$ double underlined. The transcriptional start site identified by RNA-Seq [29] in strain ATCC13032 is highlighted in magenta, the transcriptional start sites identified by primer extension and RACE in strain ATCC13689 [19] are indicated in blue. The deduced -10 regions are shown in grey boxes. The FtsR-binding site identified in this work is highlighted in yellow. The 30-bp region used for EMSAs with purified FtsR-Strep is underlined. $\mathbf{d}$ In vitro DNAbinding studies with FtsR-Strep. Purified FtsR-Strep was incubated in the indicated concentrations with a constant concentration (1 $\mu \mathrm{M})$ of a $30-$ bp double-stranded oligonucleotide covering the predicted FtsR-binding site in the ftsZ-promoter region. The mixture was then analyzed by electrophoresis using a non-denaturing 15\% (w/v) polyacrylamide gel. As negative control, a DNA fragment of the promoter region of cg 1081 was used $(1 \mu \mathrm{M})$

The DNA-binding motif shown above was used to search for similar motifs in the fts $Z$ promoter regions of other actinobacterial species possessing FtsR homologs using Clustal Omega [47]. All analyzed promoters contained a similar motif (Fig. 6a), supporting the assumption that regulation of $f t s Z$ expression by FtsR homologs is a conserved mechanism in FtsR-containing Actinobacteria. The motif generated from the proposed binding sites also represents a 25 bp inverted repeat (Fig. 6b), which is very similar to the one derived from the C. glutamicum sequences enriched by ChAP-Seq with FtsR (Fig. 5b).
In vitro binding of purified FtsR to the proposed binding motif in the fts $Z$ promoter region

To test whether purified FtsR is able to bind to the proposed binding motif in the fts $Z$ promoter region, FtsR-Strep was overproduced in $C$. glutamicum ATCC13032 $\Delta$ ftsR using plasmid pAN6-ftsR-Strep and purified using StrepTactin-Sepharose (Additional file 1: Figure S11A). As described above, FtsR-Strep could complement the growth defect of the ATCC13032 $\Delta$ ftsR mutant to the same extent as native FtsR, indicating that the StrepTag did not negatively influence FtsR activity. Size-exclusion 


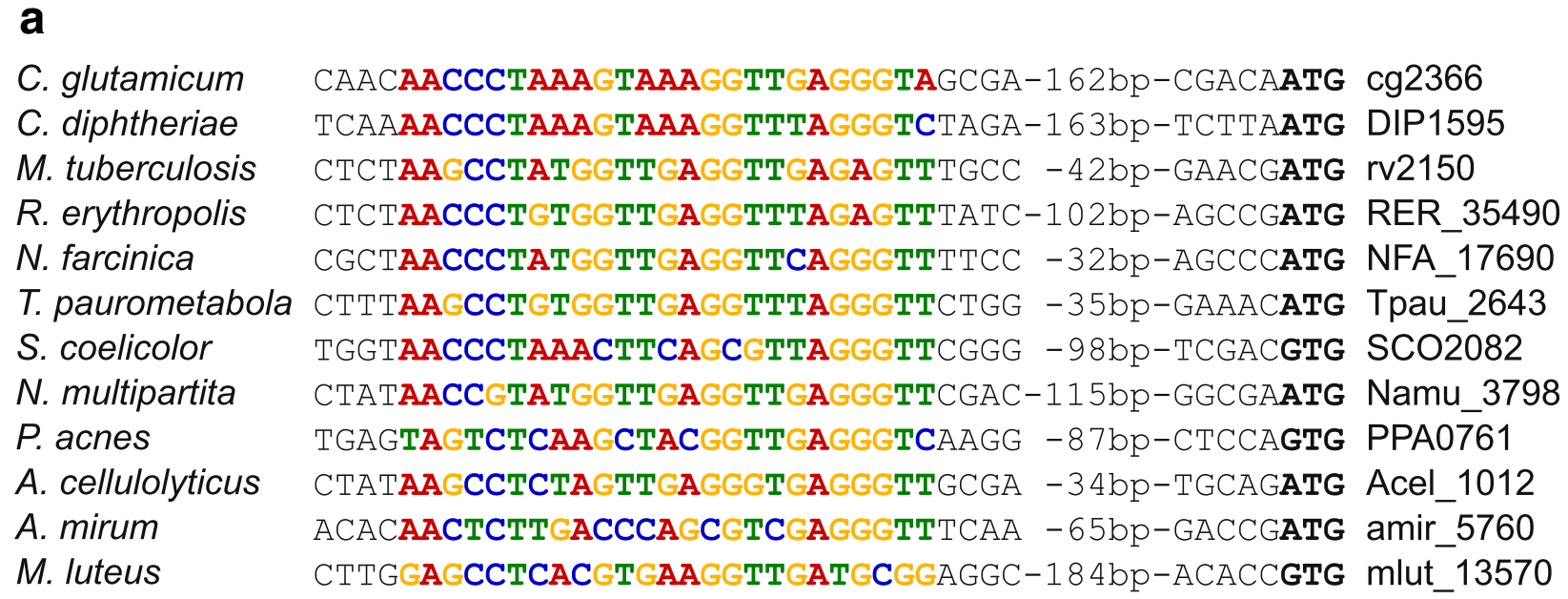

b

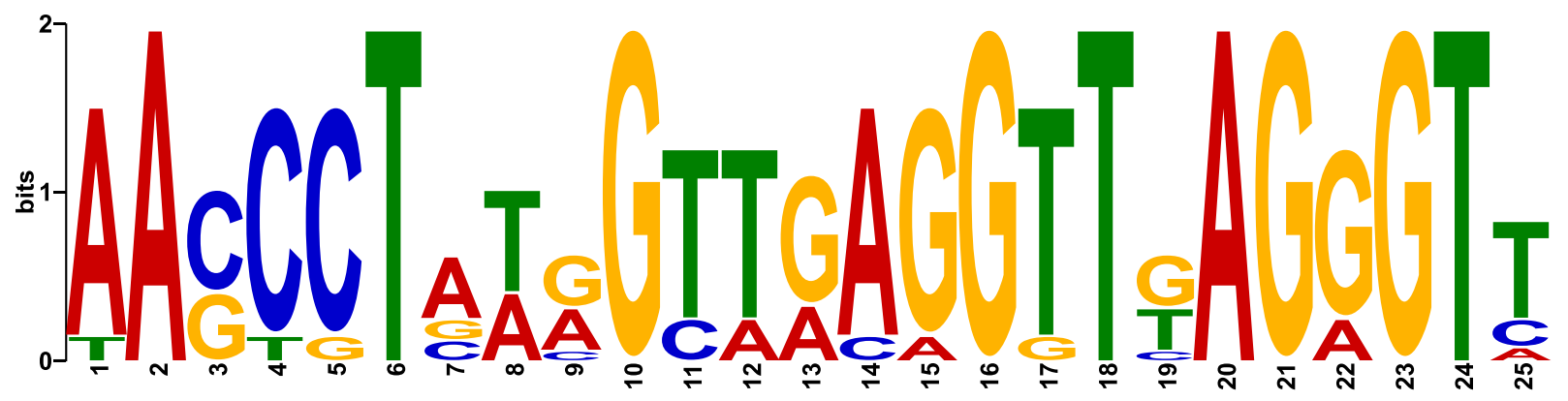

Fig. 6 Putative FtsR binding sites in the fts $Z$ promoters of various actinobacteria. a Proposed FtsR binding sites in the fts $Z$ promoters of several actinobacterial species identified by sequence alignment with the FtsR binding site in the C. glutamicum fts $Z$ promoter. The respective fts $Z$ locus tags are given on the right. The proposed binding motifs are shown as colored letters. The annotated start codons of the FtsZ proteins are indicated by bold letters. The distance between the proposed FtsR binding site and the start codon varies from 41 to 193 bp. b Consensus DNAbinding motif generated by MEME from the sequences shown in a using default parameters

chromatography of affinity-purified FtsR-Strep (calculated mass $28.5 \mathrm{kDa}$ ) and comparison to standard proteins indicated that the protein forms a dimer (Additional file 1: Figure S11B). This is in line with the dimeric state of the homologous protein Rv1828 [40]. Purified FtsR-Strep was able to completely shift a 30-bp double-stranded oligonucleotide covering the predicted FtsR-binding site in the fts $Z$ promoter region at a 2 -fold molar excess of the dimeric protein (Fig. 5d). In contrast, a control 30-bp double-strandoligonucleotide derived from the promoter region of cg1081 was incompletely shifted even at an 8.5-fold molar excess of dimeric FtsR-Strep. The specificity of this interaction was further tested using a competition-EMSA (Additional file 1: Figure S12). A Cy3-labelled 271-bp DNA fragment covering the fts $Z$ promoter region including the FtsR binding site was incubated with FtsR protein and increasing concentrations of either specific (same fragment as above) or unspecific unlabeled competitor DNA. Only the specific competitor DNA reversed the shift of the labelled DNA fragment by FtsR, supporting its specific binding to the fts $Z$ promoter region.

\section{FtsR-independent expression of FtsZ}

It is known from previous studies that differences in fts $Z$ expression cause aberrant cell morphology and FtsZ localization in C. glutamicum [19]. In order to test whether the altered cell morphology and the growth defect of the $\Delta f t s R$ mutant are solely caused by the differences in fts $Z$ expression, we constructed strains in which the expression of $f t s Z$ is independent of FtsR and controlled by the gluconate-inducible $g n t K$ promoter of C. glutamicum [19, 37, 48]. A DNA fragment containing a terminator sequence and the $g n t K$ promoter was inserted between the native $f t s Z$ promoter and the ribosome binding site of fts $Z$ within the chromosomes of $C$. glutamicum MB001 and MB001 $\triangle$ ftsR by double homologous recombination (Fig. 7a). The promoter exchange strains MB001:: $\mathrm{P}_{\text {gnt } K}-\mathrm{fts} Z$ and MB001 $\Delta$ ftsR:: $\mathrm{P}_{\text {gnt } K}-\mathrm{fts} Z$ showed growth in CGXII medium containing gluconate, but not in medium containing only glucose or sucrose, confirming gluconate-inducible fts $Z$ expression (Additional file 1: Figure S13). 
In order to analyze the consequences of different fts $Z$ expression levels on growth and morphology, cells were cultivated in CGXII medium with $2 \%(\mathrm{w} / \mathrm{v})$ glucose supplemented with $0.005,0.01,0.05$, and $0.1 \%(\mathrm{w} / \mathrm{v})$ gluconate. Strain MB001::P $\mathrm{P}_{\text {gnt }}-\mathrm{fts} Z$ showed enlarged cells with thickened poles at the lowest gluconate concentrations and reverted back to wild-type morphology at $0.1 \%(\mathrm{w} / \mathrm{v})$ gluconate (Fig. 7b). Strain MB001 $\Delta t s R:: P_{\text {gnt } K}-f t s Z$ displayed strongly branched cells at the two lowest gluconate concentrations and even at $0.1 \%(\mathrm{w} / \mathrm{v})$ gluconate the cells were still enlarged compared to the ftsR-positive strain (Fig. 7b). With respect to growth, the two strains showed quite similar growth behavior at the lowest gluconate concentration. Increased gluconate concentrations strongly improved growth of the ftsR-positive strain (Fig. 7c), whereas growth of the ftsR-negative strain was only marginally increased (Fig. 7d).

Overall, these results demonstrate the importance of an appropriate FtsZ level for normal cell morphology and growth, but they also show that the branched cells of the $\Delta f t s R$ mutant are not solely caused by reduced fts $Z$ expression, but presumably also by altered expression of other genes as a consequence of the $f t s R$ deletion.

a

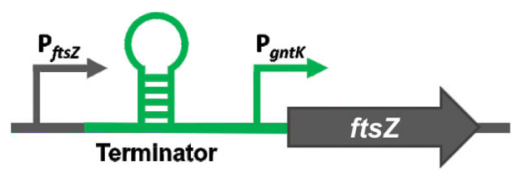

b

gluconate concentration $(w / v)$

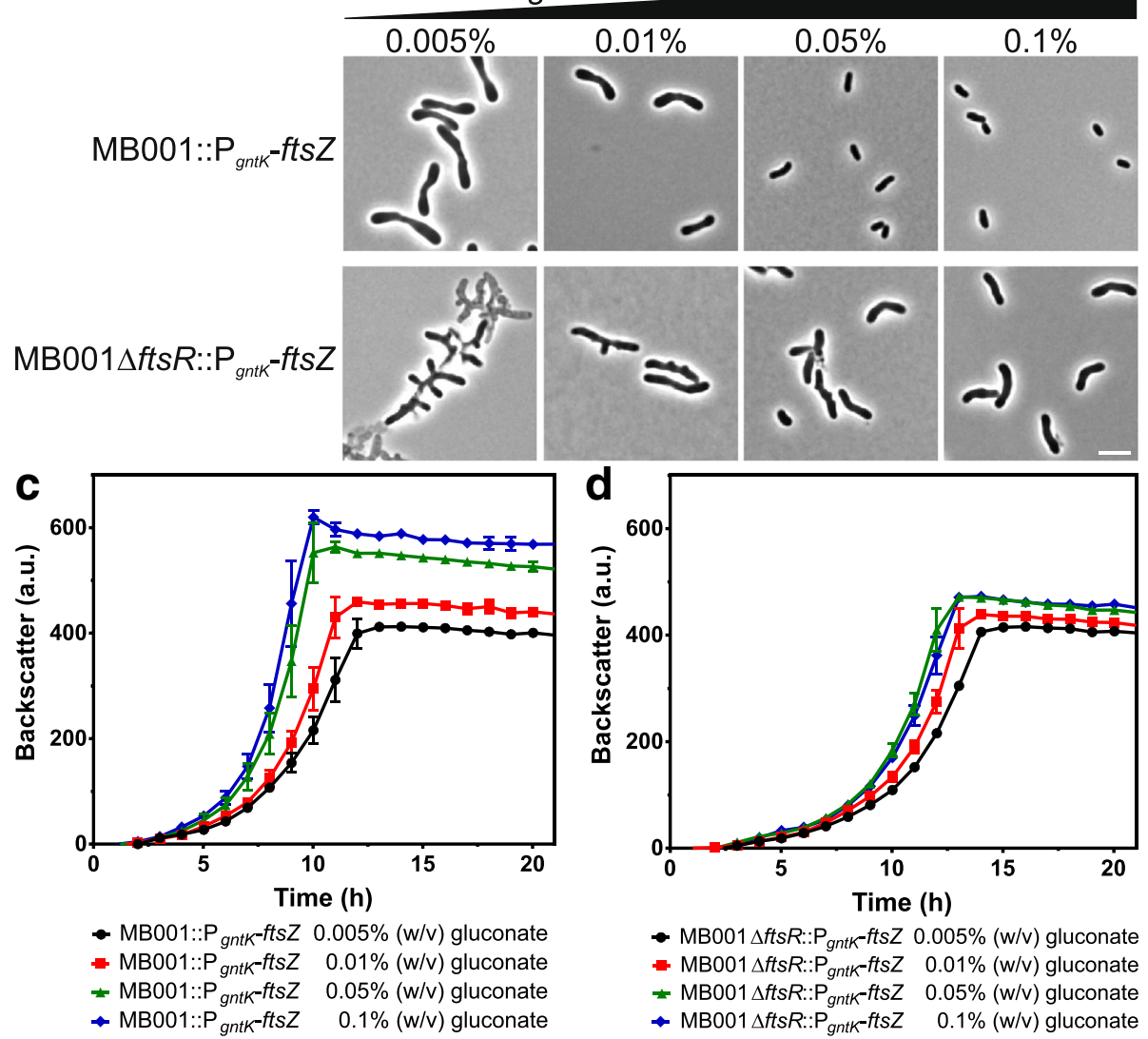

Fig. 7 Promoter exchange of ftsZ and growth of the resulting strains. a Strains with FtsR-independent ftsZ expression were constructed using a DNA fragment with a terminator sequence and the gluconate-inducible gntK promoter, which was inserted between the native fts $Z$ promoter and the ftsZ start codon in the chromosomes of MB001 and the MB001 $\triangle \mathrm{fts} R$ mutant. $\mathbf{b}$-d Effect of different gluconate concentrations on cell

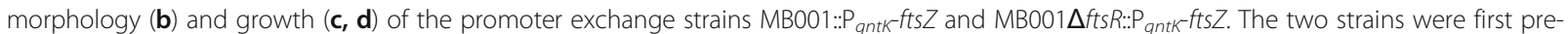
cultivated in BHI medium supplemented with $0.1 \%(\mathrm{~W} / \mathrm{v})$ gluconate to induce $\mathrm{fts} Z$ expression by $\mathrm{P}_{\text {gnt }}$. The second pre-cultivation was performed in CGXII medium with $2 \%(\mathrm{w} / \mathrm{v})$ glucose supplemented with the indicated gluconate concentrations. The main cultures were then performed in media having the same composition as the ones for the second pre-cultivation. $\mathbf{b}$ Microscopic pictures of cells from the stationary phase. The scale bar represents $5 \mu \mathrm{m}$. c, d The growth experiments show mean values and standard deviations of three biological replicates 
Similarly, the growth defect of the $\Delta f t s R$ mutant cannot be rescued simply by increased expression of fts $Z$ and thus involves further genes. These could either be direct target genes of FtsR or genes whose expression is indirectly influenced by the absence of FtsR. In additional experiments, the promoter exchange strains with FtsRindependent $f t s Z$ expression were also used to confirm transcriptional activation of fts $Z$ expression by FtsR using the reporter plasmid pJC1- $\mathrm{P}_{f t s} Z^{-v e n u s}$ (see Supplemental results and Additional file 1: Figure S14).

\section{Discussion}

The tubulin-like GTPase FtsZ plays the key role in bacterial cell division [49]. In this study, we identified the transcriptional regulator FtsR that functions as activator of $f t s Z$ expression in C. glutamicum, representing a novel control mechanism of actinobacterial cytokinesis. FtsR was initially enriched by DNA affinity chromatography with the $f t s Z$ promoter region. In vivo binding of FtsR to the $f t s Z$ promoter was confirmed by ChAP-Seq experiments and purified FtsR was shown to bind to a $30 \mathrm{bp}$-DNA fragment covering the proposed DNA-binding site of FtsR, which represents an imperfect 25-bp inverted repeat. Evidence for the activation of $f t s Z$ expression by FtsR came from transcriptome analysis, where the fts $Z$ mRNA level was significantly reduced in the $\triangle f t s R$ mutant, and reporter gene studies showing reduced activity of the ftsZ promoter in the $\Delta f t s R$ background.

Bioinformatic analyses revealed that FtsR belongs to the MerR superfamily of transcriptional regulators, which mostly function as activators, responding to a vast diversity of stimuli including oxidative stress, xenobiotics, and metal ion stress [50,51]. MerR-type regulators typically bind as homodimers to inverted repeats in the promoter region of their target genes. The binding sites can be located between the -10 and -35 regions, which then show a spacing of $19-20 \mathrm{bp}$ rather than the optimal 16-18 bp. This hampers transcription because the -10 and -35 regions are located on opposite sides of the DNA strand [51]. A well-described mechanism of transcriptional activation by regulators of the MerR superfamily is thought to rely on a conformational change of the N-terminal DNA-binding region after recognition of a stimulus by the C-terminal domain, which causes a twist of the bound DNA molecule in a manner that the -10 and -35 regions are rearranged, enabling RNA polymerase to bind and initiate transcription [52-55]. FtsR eluted as dimer during gel filtration and the binding site identified in the fts $Z$ promoter region was found to be an inverted repeat, which was located at position -61 to -85 upstream of the $f t s Z$ transcriptional start site identified by RNA-Seq [29] rather than between the
-10 and -35 regions. This position is compatible with an activating function of FtsR, but might involve a different mechanism of transcriptional activation than the one described above.

It should be mentioned that in C. glutamicum strain ATCC13689 five transcriptional start sites were identified for fts $Z$ by RACE and primer extension experiments [19], none of which corresponds to the one identified by RNA-Seq for strain ATCC13032 [29]. Further studies are required to test for the presence of additional transcriptional start sites of the fts $Z$ gene in strain ATCC13032, in which the FtsR binding site might be located between the -10 and -35 regions. Multiple promoters for ftsZ expression appear to be the rule in various bacteria such as $M$. tuberculosis [22, 24], E. coli [23], Streptomyces coelicolor A3 [2] [56], or Streptomyces griseus [57]. They allow a dynamic adjustment of the FtsZ levels according to different stimuli and probably make the cells more robust with respect to spontaneous mutations in the fts $Z$ promoter region.

FtsR was found to be conserved in many different families of Actinobacteria, including the genus Mycobacterium. In a ChIP-Seq experiment with the FtsR homolog Rv1828 of M. tuberculosis, the promoter region of the ftsZ gene was the top target [58-60]. Using the proposed binding motif of FtsR (AACCCTAAAGTAAA GGTTGAGGGTA) as template, we identified a very similar sequence (AACtCTAAgcctAtGGTTGAGGtTt) in the fts $Z$ promoter of $M$. tuberculosis, the region which also showed by far the highest coverage in the ChIP-Seq experiment [59]. Here the motif was located exactly between the -10 and -35 regions of the transcriptional start site P1, which is located at position -43 relative to the fts $Z$ translational start [24]. The binding motif proposed for Rv1828 in a recent study is different but overlaps partially with our motif [40]. Mutational analysis of this binding motif by EMSAs revealed that binding of Rv1828 is not influenced when the specific part of the motif is altered that does not overlap with our proposed binding motif [40]. This, together with the strong conservation of our motif among many species, suggests that the motif proposed by us is more likely the correct one. Our results obtained for FtsR and Rv1828 together with the recently published characterization of Rv1828 [40] strongly support the notion that FtsR and its actinobacterial homologs are involved in transcriptional regulation of fts $Z$. In line with this, the fts $Z$ promoter regions of various actinobacterial genera were found to contain DNA sequence motifs similar to the ones determined for FtsR and Rv1828 (Fig. 6).

Deletion and overexpression of fts $R$ led to growth inhibition and an altered cell morphology. The deletion phenotype could be reversed by plasmid-based expression of ftsR or the ftsR homologs of $C$. diphtheriae and 
M. tuberculosis (Fig. 3, Additional file 1:Figures. S2, S3, S4). The fact that many $\Delta$ ftsR cells and also ftsR overexpression cells contained multiple septa indicates that cell division is disturbed. The studies with the promoter exchange strains, in which fts $Z$ expression was controlled by the gluconate-inducible gntK promoter, revealed that growth behavior and morphology of the $\triangle f t s R$ mutant are not solely caused by altered fts $Z$ expression. Despite comparable fts $Z$ expression, the $\Delta f t s R$ strain grew much worse than the ftsR-positive reference strain (Fig. 7c, d) and the morphology of the $\Delta f t s R$ strain differed from the ftsR $R^{+}$strain, in particular by the formation of branched cells (Fig. 7b). This suggests that i) FtsZ alone is not the cause for the branching phenotype, and ii) there must be some other, FtsR-dependent gene that causes enlarged cells even in the presence of sufficient FtsZ.

Potential further target genes of FtsR were deduced by combining ChAP-Seq and transcriptome results. The target with the most obvious relation to the altered cell morphology of the $\Delta f t s R$ mutant was the cop1-cg3181-cg3182 gene cluster. These three genes encode secreted proteins and Cop1 (Csp1), a mycolyltransferase converting trehalose monocorynomycolate to trehalose dicorynomycolate. The mycolyl transferase function was located in the $\mathrm{N}$-terminal portion of Cop1 [43]. A C. glutamicum cop1 deletion mutant had an altered cell morphology characterized by enlarged, club-shaped cells and it was speculated that the C-terminal part of Cop1 plays a role in cell shape formation [42]. In the case of cop1, the FtsR-binding site (AAGTCTAAAGTTGAACTTAAGATTG) starts downstream of the -35 region and ends downstream of the -10 region (TAAGAT). The transcriptome data suggest a repression of cop1 by FtsR and the morphology of the cells overexpressing ftsR (Fig. 3c, Additional file 1: Figure S3) resemble that of cells lacking functional cop1 [42]. Further studies are required to confirm the influence of FtsR on the expression of the cop1-cg3181-cg3182 gene cluster and to identify further target genes and their function.

Regarding the physiological function of FtsR, a possible role could be to serve as a regulatory mechanism that controls cell division in response to the nutritional status of the cell. In recent years, several studies have revealed metabolic enzymes to directly influence cell division by modulating the activity of FtsZ [61]. Transcriptional regulation, such as shown here for FtsR, is another means to influence FtsZ activity. The fact that FtsR activates $f t s Z$ expression suggests that FtsR signals favorable nutritional conditions with a high cell division rate and thus a high FtsZ demand. As the $\mathrm{fts} R$ gene and its homologs in other Actinobacteria are always located downstream of the odhI/garA gene, a functional link to
OdhI/GarA might exist. OdhI/GarA controls the metabolic flux at the 2-oxoglutarate node of metabolism, which is particularly relevant for nitrogen assimilation. Our preliminary attempts to find a potential ligand of FtsR were not successful and the identification of the stimulus controlling FtsR activity is ultimately required to understand the function of this regulator.

\section{Conclusion}

In this study, we identified and characterized FtsR as the first transcriptional regulator of FtsZ described for $C$. glutamicum. Deletion or overexpression of ftsR had severe effects on growth and cell morphology, underlining the importance of FtsR for correct cell division. The fact that FtsR activates fts $Z$ expression suggests that FtsR might sense favorable nutritional conditions that allow for a high cell division rate and therefore require high FtsZ levels. In summary, our findings provide a first insight into transcriptional regulation of cell division in Actinobacteria.

\section{Methods}

Bacterial strains, plasmids and growth conditions

Bacterial strains and plasmids used in this study are listed in Additional file 1: Table S2. The C. glutamicum type strain ATCC13032 or its prophage-free variant $C$. glutamicum MB001 were used as wild type or reference strain, as indicated. The parental strain ATCC13032 (DSM No. 20300) was obtained from the German Collection of Microorganisms and Cell Cultures $\mathrm{GmbH}$ (DSMZ, Braunschweig, Germany). The prophage-free strain MB001 is from in-house stock and can also be obtained from the DSMZ (DSM No. 102070). For growth experiments, C. glutamicum was precultivated for $6-8 \mathrm{~h}$ at $30^{\circ} \mathrm{C}$ and $170 \mathrm{rpm}$ in $5 \mathrm{~mL}$ BHI medium (BD Bacto ${ }^{\text {tw }}$ Brain Heart Infusion, Becton Dickinson and Company, Heidelberg, Germany). The cells were harvested by centrifugation, washed with phosphate-buffered saline (PBS, $137 \mathrm{mM} \mathrm{NaCl}, 2.7 \mathrm{mM} \quad \mathrm{KCl}, 4.3 \mathrm{mM}$ $\left.\mathrm{Na}_{2} \mathrm{HPO}_{4}, 1.4 \mathrm{mM} \mathrm{K \textrm {H } _ { 2 }} \mathrm{PO}_{4}, \mathrm{pH} 7.3\right)$ and used as inoculum for a second preculture in $20 \mathrm{~mL}$ CGXII minimal medium [62] containing $30 \mathrm{mg} / \mathrm{L} \mathrm{3,4-dihydroxybenzoate}$ as iron chelator and, if not stated otherwise, 2\% (w/v) glucose as carbon source. This preculture was incubated overnight at $30^{\circ} \mathrm{C}$ and $120 \mathrm{rpm}$ and after harvesting the cells were washed in PBS and used for inoculation of the main culture, using again CGXII medium with $30 \mathrm{mg} / \mathrm{L} \mathrm{3}$, 4-dihydroxybenzoate and $2 \%(\mathrm{w} / \mathrm{v})$ glucose. Growth experiments were either performed in $100 \mathrm{~mL}$ shake flasks with $20 \mathrm{~mL}$ medium (initial optical density at $600 \mathrm{~nm}$ $\left(\mathrm{OD}_{600}\right)$ of 1.0) that were shaken at $30^{\circ} \mathrm{C}$ and $120 \mathrm{rpm}$ or in 48-well FlowerPlates (m2p-labs $\mathrm{GmbH}$, Baesweiler, Germany) with a culture volume of $800 \mu \mathrm{L}$ (initial $\mathrm{OD}_{600}$ of 0.5$)$ that were shaken in a BioLector (m2p-labs $\mathrm{GmbH}$, 
Baesweiler, Germany) at $30^{\circ} \mathrm{C}$ and $1200 \mathrm{rpm}$. Growth was monitored as cell density by determining either $\mathrm{OD}_{600}$ (shake flasks) or as scattered light at $620 \mathrm{~nm}$ in the BioLector [63], which is termed "backscatter" throughout this study. For growth experiments with promoter exchange strains where expression of the fts $Z$ gene was under control of the gntK promoter, the first pre-culture was supplemented with $0.1 \%(\mathrm{w} / \mathrm{v})$ gluconate and the second pre-culture were supplemented with $0.01 \%(\mathrm{w} / \mathrm{v})$ gluconate and $1.99 \%(\mathrm{w} / \mathrm{v})$ glucose as carbon source. The gluconate concentration of the main culture is indicated for each experiment. For cloning purposes, Escherichia coli $\mathrm{DH} 5 \alpha$ was used and routinely cultivated at $37^{\circ} \mathrm{C}$ in lysogeny broth (LB) [64]. When required, the media were supplemented with $25 \mu \mathrm{g} / \mathrm{mL}$ kanamycin or $10 \mu \mathrm{g} / \mathrm{mL}$ chloramphenicol for C. glutamicum or with $50 \mu \mathrm{g} / \mathrm{mL}$ kanamycin or $34 \mu \mathrm{g} / \mathrm{mL}$ chloramphenicol for $E$. coli.

\section{Recombinant DNA work and construction of insertion and deletion mutants}

Routine methods such as PCR, DNA restriction and ligation, Gibson assembly and transformation were performed using standard protocols [64-67]. Phusion Green High Fidelity DNA Polymerase (Thermo Fisher Scientific Inc., Rockford, IL, USA) was used for cloning purposes. For all other PCRs, either the KAPA2G Fast ReadyMix PCR Kit (Kapa Biosystems, Wilmington, USA) or DreamTaq DNA Polymerase (Thermo Fisher Scientific Inc., Rockford, IL, USA) were used. The oligonucleotides used in this study are listed in Additional file 1: Table S3 and were purchased from Eurofins Genomics $\mathrm{GmbH}$ (Ebersberg, Germany). DNA sequencing was performed by Eurofins Genomics $\mathrm{GmbH}$. The $\Delta f t s R$ mutants of C. glutamicum and the promoter exchange strains carrying a DNA fragment with a transcription terminator and the gntK promoter inserted into the chromosome between the native fts $Z$ promoter and the fts $Z$ coding region were constructed via a two-step homologous recombination protocol as described $[37,68,69]$ using plasmids pK19mobsacB- $\Delta$ ftsR and pK19mobsacB-P $\mathrm{P}_{\text {gnt } K}-\mathrm{fts} Z$. The strains ATCC13032::ftsZ-venus and ATCC13032 $\Delta$ ftsR::ftsZ-venus were constructed by chromosomal insertion of pK18mob-ftsZ-venus by single homologous recombination. In all tested clones of both strains, the plasmid did not insert into the intergenic region between cg1121 and cg1122, but in the fts $Z$ region. As the insertion plasmid was constructed in such a way that these mutants also carry one native copy of fts $Z$ and one fused to venus, these strains were used for microscopy, anyway.

\section{Fluorescence microscopy}

C. glutamicum cells were centrifuged and suspended in PBS containing $100 \mathrm{ng} / \mathrm{mL}$ Hoechst 33342 dye to stain DNA and $300 \mathrm{ng} / \mathrm{mL}$ Nile red to stain membranes
(Sigma-Aldrich Chemie GmbH, Taufkirchen, Germany). After $10 \mathrm{~min}$ of incubation in the dark at room temperature, samples were spotted onto a glass slide covered with a thin agarose layer $(1 \%(w / v)$ in TAE buffer ( $40 \mathrm{mM}$ Tris, $1 \mathrm{mM} \mathrm{Na}{ }_{2}$ EDTA, $20 \mathrm{mM}$ glacial acetic acid, $\mathrm{pH}$ 8)) and analyzed using a Zeiss Axio Imager M2 microscope equipped with a Zeiss AxioCam MRm camera (Carl Zeiss AG, Oberkochen, Germany). Images were acquired using a Plan-Apochromat 100×/1.40-numerical aperture phase contrast oil immersion objective and AxioVision 4.8 software (Carl Zeiss Microscopy $\mathrm{GmbH}$, Jena, Germany). Hoechst 33342 fluorescence was visualized with filter set 49 and Nile red with filter set $63 \mathrm{HE}$ (both Carl Zeiss AG). C. glutamicum strains producing the FtsZ-Venus fusion protein were directly used for microscopy without further staining.

\section{Purification of FtsR}

FtsR-Strep was purified using C. glutamicum ATCC13032 $\Delta$ ftsR carrying plasmid pAN6-FtsR-Strep. The preculture was prepared using a single colony from a fresh BHI agar plate to inoculate $20 \mathrm{~mL}$ BHI with $2 \%$ (w/v) glucose and $25 \mu \mathrm{g} / \mathrm{mL}$ kanamycin and incubated at $30{ }^{\circ} \mathrm{C}$ and $120 \mathrm{rpm}$ for $6-8 \mathrm{~h}$. The main culture $(500 \mathrm{~mL}$ of the same medium in a $2 \mathrm{~L}$ baffled flask) was inoculated with $1 \mathrm{~mL}$ of the preculture and incubated overnight at $30^{\circ} \mathrm{C}$ and $90 \mathrm{rpm}$. On the following morning, $50 \mu \mathrm{M}$ isopropyl $\beta$-D-1-thiogalactopyranoside (IPTG) was added and the culture was incubated for additional $4 \mathrm{~h}$ at $30^{\circ} \mathrm{C}$ and $120 \mathrm{rpm}$. Subsequently, the cells were harvested by centrifugation $\left(4{ }^{\circ} \mathrm{C}, 30 \mathrm{~min}, 3399 \mathrm{~g}\right)$ and resuspended in $25 \mathrm{~mL}$ buffer A (100 mM Tris- $\mathrm{HCl}, 100$ $\mathrm{mM} \mathrm{NaCl}, \mathrm{pH} 7.5)$ supplemented with cOmplete Mini EDTA-free protease inhibitor cocktail tablets (Roche Diagnostics GmbH, Mannheim, Germany). Cell disruption was performed by five passages through a French pressure cell using a HTU-Digi-F-Press (G. Heinemann Ultraschall- und Labortechnik, Schwaebisch Gmuend, Germany) at a pressure of $103.4 \mathrm{MPa}(15,000 \mathrm{psi})$. Cell debris was removed by centrifugation for $20 \mathrm{~min}$ at $5300 \mathrm{~g}$ and $4{ }^{\circ} \mathrm{C}$, followed by ultracentrifugation for $1 \mathrm{~h}$ at $84,000 \mathrm{~g}$ and $4{ }^{\circ} \mathrm{C}$. The supernatant was used for affinity chromatography using a Strep-Tactin-Sepharose column (IBA, Göttingen, Germany) with $1 \mathrm{~mL}$ bed volume equilibrated with buffer W $(50 \mathrm{mM}$ Tris- $\mathrm{HCl}$, $250 \mathrm{mM} \mathrm{NaCl}, \mathrm{pH} 7.5)$. After the protein extract had passed, the column was washed three times with $15 \mathrm{~mL}$ buffer W (50 mM Tris- $\mathrm{HCl}, 250 \mathrm{mM} \mathrm{NaCl}, \mathrm{pH} 7.5)$ and FtsR-Strep was eluted with $10 \times 1 \mathrm{~mL}$ buffer E (buffer W with $15 \mathrm{mM}$ D-desthiobiotin obtained from Sigma-Aldrich Chemie $\mathrm{GmbH}$, Steinheim, Germany). Aliquots of the elution fractions were analyzed by SDS-PAGE [70] and the fractions containing FtsR-Strep were pooled and concentrated using Amicon Ultra-4 Centrifugal Filter 
Devices with a $10 \mathrm{kDa}$ cut-off (Merck Millipore Ltd., Carrigtwohill, Cork, Ireland). FtsR-Strep was further purified by gel filtration using a Superdex ${ }^{\text {Tn }} 200$ Increase 10/300 GL column attached to an ÄKTA ${ }^{\text {tw }}$ pure 25 system (GE Healthcare Bio-Sciences AB, Uppsala, Sweden). The column was equilibrated with buffer $\mathrm{W}$ and elution was performed with a flow rate of $0.6 \mathrm{~mL} / \mathrm{min}$.

\section{Electrophoretic mobility shift assays (EMSAs)}

Two complementary single-stranded 30-bp oligonucleotides (see Additional file 1: Table S3) covering the putative FtsR-binding motif in the fts $Z$ promoter region were annealed by heating the samples containing $10 \mu \mathrm{M}$ Tris$\mathrm{HCl} \mathrm{pH} \mathrm{8.0,} 50 \mathrm{mM} \mathrm{NaCl}, 1 \mathrm{mM}$ EDTA and $10 \mu \mathrm{M}$ of each oligonucleotide to $95^{\circ} \mathrm{C}$ for $5 \mathrm{~min}$, followed by slow cooling to room temperature. The double-stranded oligonucleotide (final concentration $1 \mu \mathrm{M}$ ) was incubated at room temperature for $30 \mathrm{~min}$ with increasing concentrations $(0-8.5 \mu \mathrm{M})$ of freshly purified dimeric FtsR protein (Additional file 1: Figure S11) in binding buffer $(10 \mathrm{mM}$ Tris- $\mathrm{HCl} \mathrm{pH} 7.5,30 \mathrm{mM} \mathrm{NaCl}, 1.5 \mathrm{mM}$ $\mathrm{Na}_{2}$ EDTA). A 30 bp fragment located in the cg1081 promoter region was used as negative control (Additional file 1: Table S3). After incubation, a suitable volume of the 5 -fold concentrated sample buffer $(0.1 \%(\mathrm{w} / \mathrm{v})$ xylene cyanol, $0.1 \%(\mathrm{w} / \mathrm{v})$ bromophenol blue, $20 \%(\mathrm{v} / \mathrm{v})$ glycerol in $1 \mathrm{x}$ TBE $(89 \mathrm{mM}$ Tris base, $89 \mathrm{mM}$ boric acid, $2 \mathrm{mM}$ $\mathrm{Na}_{2}$ EDTA)) was added and the samples were separated by native PAGE using $15 \%(\mathrm{w} / \mathrm{v})$ polyacrylamide gels in $1 \mathrm{x}$ TBE buffer. Subsequently, the DNA was stained with SYBR $^{\circ}$ Green I Nucleic Acid Gel Stain (Invitrogen, Ltd., Paisley, UK) and photographed. The competition-EMSA was performed as described previously [71]. In brief, a 271 bp DNA-fragment covering the fts $Z$ promoter region including the binding site was amplified using oligonucleotides ftsZ_prom250_fw andCy3-ftsZ_prom_rv to generate Cy3-labelled DNA or oligonucleotides ftsZ_ prom250_fw/ftsZ_prom_rv to generate unlabeled specific competitor DNA. A 260 bp DNA-fragment further upstream in the fts $Z$ promoter was amplified using the oligonucleotide-pair ftsZ_prom500_fw/ftsZ_prom250up_ rv and used as unspecific competitor DNA. Purified FtsR protein was incubated with the DNA fragment(s) in a total volume of $10 \mu \mathrm{L}$ binding buffer. After addition of loading buffer and separation by native PAGE on a $10 \%$ polyacrylamide gel, the gel was scanned using a Typhoon TrioTM scanner (GE Healthcare).

\section{Promoter activity studies with $\mathrm{P}_{\text {ftsz }}$}

In order to analyze transcriptional regulation of $f t s Z$ by FtsR in vivo, a DNA fragment covering the fts $Z$ promoter region and the native ribosomal binding site extending from position -494 to +3 with respect to the $f t s Z$ translational start site was fused to a DNA sequence coding for the fluorescent protein mVenus and cloned into the $\mathrm{pJC1}$ vector backbone (for details see Additional file 1: Tables S4 and S5). Strains carrying their chromosomal ftsZ gene either under control of its native promoter or under control of the $g n t K$ promoter were transformed with the resulting plasmid $\mathrm{pJC1}-\mathrm{P}_{f t s} Z^{-v e n u s}$. For complementation studies, the strains were additionally transformed with pEC-ftsR or pEC-XC99E as control. Growth experiments were performed in the BioLector $^{\circ}$ as described above, with additional monitoring of the fts $Z$ promoter activity by online measurement of mVenus fluorescence at an excitation wavelength of $508 \mathrm{~nm}$ and an emission wavelength of $532 \mathrm{~nm}$.

\section{Chromatin affinity purification with subsequent sequencing (ChAP-Seq)}

For ChAP-Seq experiments, C. glutamicum ATCC13032 $\Delta$ ftsR/pAN6-FtsR-Strep and as negative control C. glutamicum ATCC13032 $\Delta$ ftsR/pAN6 were cultivated as described above for FtsR purification with $10 \mu \mathrm{M}$ instead of $50 \mu \mathrm{M}$ IPTG. FtsR-Strep was purified as described above with the following alterations: after harvesting ( $15 \mathrm{~min}, 6371 \mathrm{~g}, 4^{\circ} \mathrm{C}$ ), washing with $40 \mathrm{~mL}$ $\mathrm{PBS}$, and a second centrifugation step $(15 \mathrm{~min}, 5525 \mathrm{~g}$, $4{ }^{\circ} \mathrm{C}$ ), the supernatant was discarded and the cells were suspended in $20 \mathrm{~mL}$ PBS containing $1 \%(\mathrm{w} / \mathrm{v})$ formaldehyde and incubated at room temperature for $20 \mathrm{~min}$, followed by addition of glycine to a final concentration of $125 \mathrm{mM}$ and incubation for another $5 \mathrm{~min}$ at room temperature. The cells were washed twice with $40 \mathrm{~mL}$ buffer $\mathrm{A}$ and suspended in $20 \mathrm{~mL}$ buffer $\mathrm{A}$ with a suitable amount of cOmplete Mini EDTA-free protease inhibitor cocktail tablets and $5 \mathrm{mg}$ of RNAse A (both Roche Diagnostics GmbH, Mannheim, Germany). After cell disruption using a French press as described above, the crude extract was transferred to a sonication vessel, placed in an ice bath and sonified $3 \times 30 \mathrm{~s}$ using a Branson Sonifier 250 (G. Heinemann Ultraschall- und Labortechnik, Schwaebisch Gmuend, Germany) with a pulse length of $40 \%$ and an intensity of one to shear the genomic DNA. The sonified crude extract was used for StrepTactin affinity chromatography as described above. The FtsR-containing elution fractions were pooled, 1\% $(w / v)$ SDS was added, and the samples were incubated overnight at $65^{\circ} \mathrm{C}$, followed by proteinase $\mathrm{K}$ treatment (final concentration $400 \mu \mathrm{g} / \mathrm{mL}$ ) for $3 \mathrm{~h}$ at $55^{\circ} \mathrm{C}$. The DNA in the samples was purified by phenol-chloroformisoamyl alcohol extraction [72], precipitated with ethanol and sodium acetate, washed with $70 \%(\mathrm{v} / \mathrm{v})$ ethanol, dried and dissolved in $50 \mu \mathrm{L}$ deionized water. Sequencing of the DNA fragments and data evaluation were performed as described previously [73]. Genomic binding sites of FtsR were defined to have a sequence coverage that is at least 50 -fold above the average genome 
coverage determined for the negative control strain $C$. glutamicum ATCC13032 pAN6.

\section{DNA microarrays}

DNA microarray analysis was performed to compare the mRNA levels of the ATCC13032 $\mathrm{fts} R$ mutant with the wild type. Cells were cultivated in $50 \mathrm{~mL}$ CGXII medium with $2 \%(\mathrm{w} / \mathrm{v})$ glucose and harvested on ice in the exponential growth phase. RNA sample preparation, labelling, hybridization, and comparative transcriptome analysis were performed as described previously [74]. The full data set of this experiment has been deposited in the NCBI Gene Expression Omnibus and can be found under the GEO accession number GSE107921.

\section{DNA affinity purification and MALDI-ToF-MS analysis}

To identify putative regulatory proteins binding to the fts $Z$ promoter region, DNA affinity chromatography was performed. A 404-bp DNA fragment, extending from position -285 to +96 with respect to the translational start site of fts $Z$ and including a $23 \mathrm{bp}$ overhang for the addition of the biotin-tag, was amplified by PCR using the oligonucleotides AP_PftsZ_fw and AP_PftsZ_rv_bio. The resulting fragment was tagged with biotin by a second PCR using the biotinylated oligonucleotide biotin_oligo and AP_PftsZ_fw. The PCR products were purified by size exclusion chromatography using a column with $8 \mathrm{~mL}$ Sephacry ${ }^{\mathrm{Tm}}$ S-400 High Resolution Chromatography Media (GE Healthcare BioSciences AB, Uppsala, Sweden) as bed material. Fractions containing the desired DNA fragment were pooled, concentrated to about $500 \mu \mathrm{L}$ using an Eppendorf Concentrator plus (Eppendorf AG, Hamburg, Germany) and precipitated with ethanol. The precipitate was dissolved in $50 \mu \mathrm{L}$ TE buffer and the DNA concentration was measured with a Colibri Microvolume Spectrophotometer (Berthold Detection Systems GmbH, Pforzheim, Germany) to assure a minimal amount of 220 pmol biotinylated DNA, which was required for the following steps. The DNA affinity chromatography was performed using Dynabeads ${ }^{\bullet}$ M-280 Streptavidin (Life Technologies AS, Oslo, Norway) as described [73]. In brief, the biotinylated DNA was coupled to the beads and incubated with crude cell extract of $C$. glutamicum ATCC13032 cells that had been cultivated in glucose minimal medium and harvested in the exponential growth phase. After several washing steps, the proteins were eluted using buffer containing $2 \mathrm{M} \mathrm{NaCl}$. The elution fractions were subjected to protein precipitation with trichloroacetic acid (TCA, 10\% (w/v) final concentration) and washed once with acetone. The precipitated protein was dissolved in $20 \mu \mathrm{L}$ Tris- $\mathrm{HCl}$ buffer $\mathrm{pH} 7.5$ and analyzed by SDS-PAGE [70] using a $12 \%$ Mini-PROTEAN ${ }^{\circ}$ $\mathrm{TGX}^{\mathrm{m}}$ gel (Bio-Rad Laboratories, Inc., Hercules, CA, USA). The gel was stained with GelCode ${ }^{\circ}$ Blue Stain Reagent (Thermo Fisher Scientific Inc., Rockford, IL, USA).
Proteins enriched with the promoter region of fts $Z$ were identified by peptide mass fingerprinting after tryptic ingel digestion of the excised bands of the polyacrylamide gel followed by MALDI-ToF-MS using an Ultraflex III TOF/ TOF mass spectrometer (Bruker Daltonics, Bremen, Germany) as described [75, 76].

\section{Additional file}

Additional file 1: Contains additional methods, results, figures and tables. (PDF 3699 kb)

\section{Abbreviations}

BHI: Brain Heart Infusion (complex medium for C. glutamicum); CGP1, CGP2, CGP3: C. glutamicum prophages 1, 2 and 3; CGXII: minimal medium for $C$. glutamicum; IPTG: Isopropyl ß-D-1-thiogalactopyranoside; LB: Lysogeny broth; $\mathrm{OD}_{600}$ : Optical density at $600 \mathrm{~nm}$; PBS: Phosphate buffered saline;

TCA: Trichloroacetic acid

\section{Acknowledgements}

We would like to thank Susana Matamouros and Jannick Kappelmann for their help with Coulter counter measurements and data interpretation and Christina Mack and Doris Rittmann for excellent technical assistance.

\section{Authors' contributions}

$\mathrm{MBa}$ and $\mathrm{MBo}$ designed and coordinated the study. KJK performed most of the experiments. TP generated and analyzed the NGS data for genome resequencing and the ChAP-Seq experiment. KJK, MBa, and MBo analyzed the data and wrote the manuscript. All authors read and approved the final manuscript.

\section{Funding}

No Funding was obtained for this study.

\section{Availability of data and materials}

The microarray data has been deposited in the GEO database under GSE107921 (https://www.ncbi.nlm.nih.gov/geo/query/acc.cgi?acc=GSE107921 ). All other data generated or analysed during this study are included in this published article and its supplementary information files. All plasmids and strains used in this study are available from the corresponding author.

Ethics approval and consent to participate

Not applicable.

\section{Consent for publication}

Not applicable.

\section{Competing interests}

The authors declare that they have no competing interests.

Received: 1 May 2019 Accepted: 24 July 2019

Published online: 05 August 2019

\section{References}

1. Du S, Lutkenhaus J. Assembly and activation of the Escherichia coli divisome. Mol Microbiol. 2017;105(2):177-87.

2. Hajduk IV, Rodrigues CD, Harry EJ. Connecting the dots of the bacterial cell cycle: coordinating chromosome replication and segregation with cell division. Semin Cell Dev Biol. 2016;53:2-9.

3. Wagner KS, White JM, Lucenko I, Mercer D, Crowcroft NS, Neal S, et al. Diphtheria in the postepidemic period, Europe, 2000-2009. Emerg Infect Dis. 2012;18(2):217-25.

4. Lawn SD, Zumla Al, et al. Lancet. 2011;378(9785):57-72.

5. WHO. Tuberculosis fact sheet, 2015. http://www.who.int/mediacentre/ factsheets/fs104/en/.

6. CDC. Diphtheria, 2014. http://www.cdc.gov/diphtheria/clinicians.html.

7. Eggeling L, Bott M. Editors. Handbook of Corynebacterium glutamicum. Boca Raton: CRC Press, Taylor \& Francis Group; 2005. 
8. Eggeling L, Bott M. A giant market and a powerful metabolism: L-lysine provided by Corynebacterium glutamicum. Appl Microbiol Biotechnol. 2015; 99(8):3387-94.

9. Wendisch VF, Jorge JM, Perez-Garcia F, Sgobba E. Updates on industrial production of amino acids using Corynebacterium glutamicum. World J Microbiol Biotechnol. 2016;32(6):105.

10. Becker J, Wittmann C. Bio-based production of chemicals, materials and fuels -Corynebacterium glutamicum as versatile cell factory. Curr Opin Biotechnol. 2012;23(4):631-40.

11. Freudl R. Beyond amino acids: use of the Corynebacterium glutamicum cell factory for the secretion of heterologous proteins. J Biotechnol. 2017;258: 101-9.

12. Margolin W. FtsZ and the division of prokaryotic cells and organelles. Nat Rev Mol Cell Biol. 2005;6(11):862-71.

13. Ortiz C, Natale $P$, Cueto L, Vicente $M$. The keepers of the ring: regulators of FtsZ assembly. FEMS Microbiol Rev. 2016;40(1):57-67.

14. Kruse T, Bork-Jensen J, Gerdes K. The morphogenetic MreBCD proteins of Escherichia coli form an essential membrane-bound complex. Mol Microbiol. 2005;55(1):78-89.

15. Figge RM, Divakaruni AV, Gober JW. MreB, the cell shape-determining bacterial actin homologue, co-ordinates cell wall morphogenesis in Caulobacter crescentus. Mol Microbiol. 2004;51(5):1321-32.

16. Jones $L$, Carballido-Lopez R, Errington J. Control of cell shape in bacteria: helical, actin-like filaments in Bacillus subtilis. Cell. 2001;104(6):913-22.

17. Daniel RA, Errington J. Control of cell morphogenesis in bacteria: two distinct ways to make a rod-shaped cell. Cell. 2003;113(6):767-76.

18. Donovan C, Bramkamp M. Cell division in Corynebacterineae. Front Microbiol. 2014;5:132.

19. Letek M, Ordonez E, Fiuza M, Honrubia-Marcos P, Vaquera J, Gil JA, et al. Characterization of the promoter region of fts $Z$ from Corynebacterium glutamicum and controlled overexpression of FtsZ. Int Microbiol. 2007;10(4):271-82.

20. Ramos A, Letek M, Campelo AB, Vaquera J, Mateos LM, Gil JA. Altered morphology produced by fts $Z$ expression in Corynebacterium glutamicum ATCC 13869. Microbiology. 2005;151(Pt 8):2563-72.

21. Dziadek J, Rutherford SA, Madiraju MV, Atkinson MA, Rajagopalan M Conditional expression of Mycobacterium smegmatis ftsZ, an essential cell division gene. Microbiology. 2003;149(Pt 6):1593-603.

22. Roy S, Ajitkumar P. Transcriptional analysis of the principal cell division gene, ftsZ, of Mycobacterium tuberculosis. J Bacteriol. 2005;187(7):2540-50.

23. Flardh K, Garrido T, Vicente M. Contribution of individual promoters in the $d d l B$-fts $Z$ region to the transcription of the essential cell-division gene $f t s Z$ in Escherichia coli. Mol Microbiol. 1997:24(5):927-36.

24. Kiran M, Maloney E, Lofton H, Chauhan A, Jensen R, Dziedzic R, et al. Mycobacterium tuberculosis fts $Z$ expression and minimal promoter activity. Tuberculosis (Edinb). 2009;89(Suppl 1):S60-4.

25. Lee DS, Kim P, Kim ES, Kim Y, Lee HS. Corynebacterium glutamicum WhcD interacts with WhiA to exert a regulatory effect on cell division genes. Antonie Van Leeuwenhoek. 2018;111(5):641-8.

26. Schultz C, Niebisch A, Schwaiger A, Viets U, Metzger S, Bramkamp M, et al. Genetic and biochemical analysis of the serine/threonine protein kinases PknA, PknB, PknG and PknL of Corynebacterium glutamicum: evidence for non-essentiality and for phosphorylation of Odhl and FtsZ by multiple kinases. Mol Microbiol. 2009:74(3):724-41.

27. Gerstmeir R, Cramer A, Dangel P, Schaffer S, Eikmanns BJ. RamB, a novel transcriptional regulator of genes involved in acetate metabolism of Corynebacterium glutamicum. J Bacteriol. 2004;186(9):2798-809.

28. Auchter $M$, Cramer $A$, Hüser $A$, Rückert $C$, Emer $D$, Schwarz $P$, et al. RamA and RamB are global transcriptional regulators in Corynebacterium glutamicum and control genes for enzymes of the central metabolism. J Biotechnol. 2011;154(2-3):126-39.

29. Pfeifer-Sancar K, Mentz A, Rückert C, Kalinowski J. Comprehensive analysis of the Corynebacterium glutamicum transcriptome using an improved RNAseq technique. BMC Genomics. 2013;14:888.

30. Alm E, Huang KH, Price MN, Koche RP, Keller K, Dubchak IL, et al. The MicrobesOnline web site for comparative genomics. Genome Res. 2005;15(7): 1015-22.

31. Overbeek R, Larsen N, Walunas T, D'Souza M, Pusch G, Selkov E Jr, et al. The ERGO genome analysis and discovery system. Nucleic Acids Res. 2003;31(1):164-71.

32. Altschul SF, Gish W, Miller W, Myers EW, Lipman DJ. Basic local alignment search tool. J Mol Biol. 1990;215(3):403-10.
33. Niebisch A, Kabus A, Schultz C, Weil B, Bott M. Corynebacterial protein kinase G controls 2-oxoglutarate dehydrogenase activity via the phosphorylation status of the Odhl protein. J Biol Chem. 2006;281:12300-7.

34. Krawczyk S, Raasch K, Schultz C, Hoffelder M, Eggeling L, Bott M. The FHA domain of Odhl interacts with the carboxyterminal 2-oxoglutarate dehydrogenase domain of OdhA in Corynebacterium glutamicum. FEBS Lett 2010;584(8):1463-8.

35. Raasch K, Bocola M, Labahn J, Leitner A, Eggeling L, Bott M. Interaction of 2-oxoglutarate dehydrogenase OdhA with its inhibitor Odhl in Corynebacterium glutamicum: mutants and a model. J Biotechnol. 2014; 191:99-105.

36. Ventura M, Rieck B, Boldrin F, Degiacomi G, Bellinzoni M, Barilone N, et al. GarA is an essential regulator of metabolism in Mycobacterium tuberculosis. Mol Microbiol. 2013;90(2):356-66

37. Baumgart M, Schubert K, Bramkamp M, Frunzke J. Impact of LytR-CpsA-Psr proteins on cell wall biosynthesis in Corynebacterium glutamicum. J Bacteriol. 2016:198(22):3045-59.

38. Kortmann M, Kuhl V, Klaffl S, Bott M. A chromosomally encoded T7 RNA polymerase-dependent gene expression system for Corynebacterium glutamicum: construction and comparative evaluation at the single-cell level. Microb Biotechnol. 2015:8(2):253-65.

39. Baumgart M, Unthan S, Rückert C, Sivalingam J, Grünberger A, Kalinowski J, et al. Construction of a prophage-free variant of Corynebacterium glutamicum ATCC 13032 for use as a platform strain for basic research and industrial biotechnology. Appl Environ Microbiol. 2013;79(19):6006-15.

40. Singh S, Sevalkar RR, Sarkar D, Karthikeyan S. Characteristics of the essential pathogenicity factor Rv1828, a MerR family transcription regulator from Mycobacterium tuberculosis. FEBS J. 2018:285(23):4424-44.

41. Bailey TL, Boden M, Buske FA, Frith M, Grant CE, Clementi L, et al. MEME SUITE: tools for motif discovery and searching. Nucleic Acids Res. 2009;37(Web Server issue):W202-8.

42. Brand S, Niehaus K, Pühler A, Kalinowski J. Identification and functional analysis of six mycolyltransferase genes of Corynebacterium glutamicum ATCC 13032: the genes cop1, cmt1, and cmt2 can replace each other in the synthesis of trehalose dicorynomycolate, a component of the mycolic acid layer of the cell envelope. Arch Microbiol. 2003:180(1):33-44.

43. Puech V, Bayan N, Salim K, Leblon G, Daffe M. Characterization of the in vivo acceptors of the mycoloyl residues transferred by the corynebacterial PS1 and the related mycobacterial antigens 85. Mol Microbiol. 2000;35(5):1026-41.

44. Schaaf S, Bott M. Target genes and DNA-binding sites of the response regulator PhoR from Corynebacterium glutamicum. J Bacteriol. 2007;189(14):5002-11.

45. Wendisch VF, Bott M. Phosphorus metabolism of Corynebacterium glutamicum. In: Eggeling L, Bott M, editors. Handbook of Corynebacterium glutamicum. Boca Raton: CRC Press; 2005. p. 377-96.

46. Ishige T, Krause M, Bott M, Wendisch VF, Sahm H. The phosphate starvation stimulon of Corynebacterium glutamicum determined by DNA microarray analyses. J Bacteriol. 2003;185(15):4519-29.

47. Sievers F, Wilm A, Dineen D, Gibson TJ, Karplus K, Li W, et al. Fast, scalable generation of high-quality protein multiple sequence alignments using Clustal Omega. Mol Syst Biol. 2011;7:539.

48. Frunzke J, Engels V, Hasenbein S, Gätgens C, Bott M. Co-ordinated regulation of gluconate catabolism and glucose uptake in Corynebacterium glutamicum by two functionally equivalent transcriptional regulators, GntR1 and GntR2. Mol Microbiol. 2008;67(2):305-22.

49. Adams DW, Errington J. Bacterial cell division: assembly, maintenance and disassembly of the $Z$ ring. Nat Rev Microbiol. 2009;7(9):642-53.

50. McEwan AG, Djoko KY, Chen NH, Couñago RLM, Kidd SP, Potter AJ, et al. Novel bacterial MerR-like regulators: their role in the response to carbonyl and nitrosative stress. Adv Microb Physiol. 2011; Volume 58: $1-22$

51. Brown NL, Stoyanov JV, Kidd SP, Hobman JL. The MerR family of transcriptional regulators. FEMS Microbiol Rev. 2003;27(2-3):145-63.

52. Ansari AZ, Chael ML, O'Halloran TV. Allosteric underwinding of DNA is a critical step in positive control of transcription by hg-MerR. Nature. 1992; 355(6355):87-9.

53. Frantz B, O'Halloran TV. DNA distortion accompanies transcriptional activation by the metal-responsive gene-regulatory protein MerR. Biochemistry. 1990:29(20):4747-51.

54. Newberry KJ, Brennan RG. The structural mechanism for transcription activation by MerR family member multidrug transporter activation. N terminus J Biol Chem. 2004;279(19):20356-62. 
55. Philips SJ, Canalizo-Hernandez M, Yildirim I, Schatz GC, Mondragon A, O'Halloran TV. Allosteric transcriptional regulation via changes in the overall topology of the core promoter. Science. 2015;349(6250):877-81.

56. Flardh $\mathrm{K}$, Leibovitz E, Buttner MJ, Chater KF. Generation of a non-sporulating strain of Streptomyces coelicolor A3(2) by the manipulation of a developmentally controlled ftsZ promoter. Mol Microbiol. 2000;38(4):737-49.

57. Kwak J, Dharmatilake AJ, Jiang H, Kendrick KE. Differential regulation of ftsZ transcription during septation of Streptomyces griseus. J Bacteriol. 2001: 183(17):5092-101.

58. Galagan JE, Sisk P, Stolte C, Weiner B, Koehrsen M, Wymore F, et al. TB database 2010: overview and update. Tuberculosis (Edinb). 2010;90(4):225-35.

59. Minch KJ, Rustad TR, Peterson EJ, Winkler J, Reiss DJ, Ma S, et al. The DNA -binding network of Mycobacterium tuberculosis. Nat Commun. 2015;6:5829.

60. Reddy TB, Riley R, Wymore F, Montgomery P, DeCaprio D, Engels R, et al. TB database: an integrated platform for tuberculosis research. Nucleic Acids Res. 2009;37(Database issue):D499-508.

61. Monahan LG, Harry EJ. You are what you eat: metabolic control of bacterial division. Trends Microbiol. 2016;24(3):181-9.

62. Keilhauer C, Eggeling L, Sahm H. Isoleucine synthesis in Conynebacterium glutamicum - molecular analysis of the IIVB-IIVN-IIVC operon. J Bacteriol. 1993;175(17):5595-603.

63. Kensy F, Zang E, Faulhammer C, Tan RK, Büchs J. Validation of a highthroughput fermentation system based on online monitoring of biomass and fluorescence in continuously shaken microtiter plates. Microb Cell Factories. 2009;8:31.

64. Sambrook J, Russell D. Molecular cloning. A laboratory manual. 3rd ed. Cold Spring Harbor: Cold Spring Harbor Laboratory Press; 2001.

65. Hanahan D. Studies on transformation of Escherichia coli with plasmids. J Mol Biol. 1983;166(4):557-80.

66. van der Rest ME, Lange C, Molenaar D. A heat shock following electroporation induces highly efficient transformation of Corynebacterium glutamicum with xenogeneic plasmid DNA. Appl Microbiol Biotechnol. 1999;52(4):541-5.

67. Gibson DG, Young L, Chuang RY, Venter JC, Hutchison CA 3rd, Smith HO. Enzymatic assembly of DNA molecules up to several hundred kilobases. Nat Methods. 2009;6(5):343-5.

68. Schäfer A, Tauch A, Jäger W, Kalinowski J, Thierbach G, Pühler A. Small mobilizable multi-purpose cloning vectors derived from the Escherichia coli plasmids pK18 and pK19: selection of defined deletions in the chromosome of Corynebacterium glutamicum. Gene. 1994;145(1):69-73.

69. Niebisch A, Bott M. Molecular analysis of the cytochrome $b c_{1}-a a_{3}$ branch of the Corynebacterium glutamicum respiratory chain containing an unusual diheme cytochrome $c_{1}$. Arch Microbiol. 2001;175(4):282-94.

70. Laemmli UK. Cleavage of structural proteins during the assembly of the head of bacteriophage T4. Nature. 1970;227:680-5.

71. Garcia-Nafria J, Baumgart M, Turkenburg JP, Wilkinson AJ, Bott M, Wilson KS. Crystal and solution studies reveal that the transcriptional regulator AcnR of Corynebacterium glutamicum is regulated by citrate- $\mathrm{Mg}^{2+}$ binding to a non -canonical pocket. J Biol Chem. 2013;288(22):15800-12.

72. Chomczynski P, Sacchi N. The single-step method of RNA isolation by acid guanidinium thiocyanate-phenol-chloroform extraction: twenty-something years on. Nat Protoc. 2006;1 (2):581-5.

73. Pfeifer E, Hünnefeld M, Popa O, Polen T, Kohlheyer D, Baumgart M, et al. Silencing of cryptic prophages in Corynebacterium glutamicum. Nucleic Acids Res. 2016;44(21):10117-31.

74. Vogt M, Haas S, Klaffl S, Polen T, Eggeling L, van Ooyen J, et al. Pushing product formation to its limit: metabolic engineering of Corynebacterium glutamicum for L-leucine overproduction. Metab Eng. 2014;22:40-52.

75. Schaffer S, Weil B, Nguyen VD, Dongmann G, Günther K, Nickolaus M, et al. A high-resolution reference map for cytoplasmic and membrane-associated proteins of Corynebacterium glutamicum. Electrophoresis. 2001;22(20):4404-22.

76. Koch-Koerfges A, Kabus A, Ochrombel I, Marin K, Bott M. Physiology and global gene expression of a Corynebacterium glutamicum $\Delta \mathrm{F}_{1} \mathrm{~F}_{\mathrm{O}}$-ATP synthase mutant devoid of oxidative phosphorylation. Biochim Biophys Acta. 2012;1817(2):370-80.

\section{Publisher's Note}

Springer Nature remains neutral with regard to jurisdictional claims in published maps and institutional affiliations.

Ready to submit your research? Choose BMC and benefit from:

- fast, convenient online submission

- thorough peer review by experienced researchers in your field

- rapid publication on acceptance

- support for research data, including large and complex data types

- gold Open Access which fosters wider collaboration and increased citations

- maximum visibility for your research: over $100 \mathrm{M}$ website views per year

At $\mathrm{BMC}$, research is always in progress.

Learn more biomedcentral.com/submissions 